Supplementary Information for:

\title{
Oxygen Activation by Co(II) and a Redox Non-Innocent Ligand: Spectroscopic Characterization of a Radical-Co(II)-Superoxide Complex with Divergent Catalytic Reactivity
}

\author{
Amanda R. Corcos, ${ }^{\dagger}$ Omar Villanueva, ${ }^{\ddagger} \nabla$ Richard C. Walroth, ${ }^{\S}$ Savita K. Sharma, ${ }^{\ddagger}$ John \\ Bacsa, ${ }^{\ddagger}$ Kyle M. Lancaster ${ }^{\S, \star}$ Cora E. MacBeth, ${ }^{\ddagger, \star}$ John F. Berry ${ }^{\dagger, *}$ \\ ${ }^{\dagger}$ Department of Chemistry, University of Wisconsin-Madison, 1101 University Ave. Madison, WI 53706 \\ ‡ Department of Chemistry, Emory University, 1515 Dickey Drive, Atlanta, GA 30322 \\ $\S$ Department of Chemistry and Chemical Biology, Baker Laboratory, Cornell University, Ithaca, NY 14853
Email: * berry@chem.wisc.edu
* cora.macbeth@emory.edu
*kml236@cornell.edu


Contents:

I. General procedures

S3

II. Synthetic procedures
A. Formation of $[\mathbf{2}]^{2-}$ S8
B. Formation of [3] ${ }^{1-}$ S8
C. Reactivity studies with [3] $]^{1-}$ S10

III. Spectroscopic Characterizations
A. Crystallographic figures for $[2]^{2-}$ S14
B. UV-Vis of [3] $]^{1-}$ S17
C. Mass Spec for $\left[{ }^{16} 3\right]^{1-}$ and $\left[{ }^{18} 3\right]^{1-}$ S18
D. $\Delta \mathrm{IR}$ of $\left[{ }^{16} 3\right]^{1-}-\left[{ }^{18} 3\right]^{1-}$ S19
E. X-ray Absorption Spectroscopy (XAS) S20

IV. Calculated Data
A. Spin density plots for $[2]^{2-}$ and $[3]^{1-}$ S25
B. Molecular orbitals for [2] ${ }^{2-}$ S26
C. Molecular orbitals for $[3]^{1}$ S27
D. Averaged atomic natural orbitals for $[3]^{1-}$ S28
E. Molecular orbitals for [3b ${ }^{1}$ S29

V. Tables
A. Crystallographic Data for [2] $]^{2-}$ S31
B. Bond lengths and angles for $[2]^{2-}$ S32
C. DFT bond lengths and angles for all species S34
D. Calculated energy differences S35
E. State energies for [3 $]^{1-}$ S36
E. XYZ coordinates for DFT-optimized geometries S37

VI. References S40 
General Procedures. All manipulations were carried out using standard Schlenk techniques or conducted in an MBraun Labmaster 130 drybox under a nitrogen atmosphere. All reagents used were purchased from commercial vendors and used as received unless otherwise noted. 2-phenylpropionaldehyde (2-PPA) was purchased from Sigma-Aldrich and its purity was checked by GC and ${ }^{1} \mathrm{H}$ NMR spectroscopy prior to use. Anhydrous solvents were purchased from Sigma-Aldrich and further purified by sparging with Ar gas followed by passage through activated alumina columns. Elemental analysis was performed by Atlantic Microlab, LLC.

${ }^{1} \mathrm{H}$ NMR spectra were recorded on an Inova $400 \mathrm{MHz}$ spectrometer at ambient temperature. ${ }^{1} \mathrm{H}$ chemical shifts were referenced to residual solvent peaks. Matrixassisted laser desorption/ionization (MALDI) time-of-flight (TOF) mass spectrometry data were obtained using an anthracene matrix on a Bruker ULTRAFLEX ${ }^{\circledR}$ III mass spectrometer equipped with a SmartBeam ${ }^{\circledR}$ laser. Liquid IR data for $[3]^{1-}$ were collected on a Bruker Tensor $27 \mathrm{FTIR}$ spectrometer, and the samples were prepared in an $\mathrm{NaCl}$ amalgamated cell. Infrared spectra for [2] ${ }^{2-}$ were recorded as $\mathrm{KBr}$ pellets on a Varian Scimitar 800 Series FT-IR spectrophotometer. UV-visible absorption spectra were recorded on a Cary50 spectrophotometer using $1.0 \mathrm{~cm}$ quartz cuvettes. Solution-state magnetic moments were measured using Evans' method. ${ }^{1} \mathrm{X}$-ray diffraction studies were carried out in the X-ray Crystallography Laboratory at Emory University on a Bruker Smart 1000 CCD diffractometer. Cyclic voltammetry experiments were carried out using a $\mathrm{CH}$ Instruments (Austin, TX) Model $660 \mathrm{C}$ potentiostat. All experiments were conducted in $\mathrm{CH}_{2} \mathrm{Cl}_{2}$ with $0.10 \mathrm{M}$ tetrabutylammonium hexafluorophosphate as the supporting electrolyte. Electrochemical experiments were conducted in a three- 
component cell consisting of a Pt-wire auxiliary electrode, a non-aqueous reference electrode $\left(\mathrm{Ag} / \mathrm{AgNO}_{3}\right)$, and a glassy-carbon working electrode.

EPR Data. EPR data were acquired using a Bruker ELEXSYS E500 EPR spectrometer equipped with a Varian E102 microwave bridge interfaced with a Linux system. An Oxford Instruments ESR-900 continuous-flow helium flow cryostat and an Oxford Instruments 3120 temperature controller were used to set and maintain the sample temperature. A Hewlett-Packard 432A power meter was used for microwave power calibration, with measurement conditions as follows: for $[2]^{2-}$ in acetonitrile $9.3750 \mathrm{GHz}$, $100 \mathrm{MHz}$ modulation frequency, $4.000 \mathrm{G}$ modulation amplitude, $4000 \mathrm{G}$ center field, $8000 \mathrm{G}$ sweep width, $3.170 \mathrm{~mW}$ power, $30 \mathrm{~dB}$ gain, $327.68 \mathrm{~ms}$ time constant, and $10 \mathrm{~K}$; for [3] ${ }^{1-}$ in acetonitrile $9.3763 \mathrm{GHz}, 100 \mathrm{MHz}$ modulation frequency, $4.000 \mathrm{G}$ modulation amplitude, $3400 \mathrm{G}$ center field, $1600 \mathrm{G}$ sweep width, $2.000 \mathrm{~mW}$ power, $55 \mathrm{~dB}$ gain, 655.36 ms time constant, and $10 \mathrm{~K}$.

Simulations were performed using EasySpin software, ${ }^{2}$ and the following

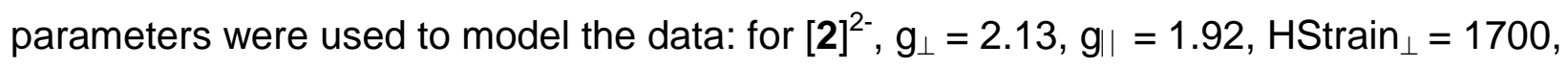
HStrain $\|=1000, E / D=0.04, S=3 / 2$, weight $=100$, with a minor impurity modeled as $g_{\perp}$ $=2.10, g_{\|}=2.01$, HStrain $_{\perp} 600$, HStrain ||$=500, S=1 / 2$, weight $=3$. Simulations for $[3]^{1-}$ are $g_{x}=2.20, g_{y}=2.00, g_{z}=1.975, A_{x, C_{0}}=250 \mathrm{MHz}$, HStrain $x=225$, HStrain $_{y}=$ 180, HStrain $_{z}=240, S=1 / 2$.

X-ray Crystallography. A burgundy block-shaped crystal of [2] ${ }^{2-}$ with dimensions $0.69 \times 0.43 \times 0.40 \mathrm{~mm}$ was mounted on a loop with paratone oil. Data were collected 
using a Bruker APEX-II CCD diffractometer equipped with an Oxford Cryosystems lowtemperature apparatus operating at $T=173(2) \mathrm{K}$. Data were measured using $\omega$ scans using Mo- $\mathrm{K}_{\alpha}$ radiation (fine-focus sealed tube, $45 \mathrm{kV}, 35 \mathrm{~mA}$ ). The total number of runs and images was based on the strategy calculation from the program APEX2. ${ }^{3}$ The maximum resolution achieved was $Q=31.50^{\circ}$. Unit cell indexing was performed by using the APEX2 software ${ }^{3}$ and refined using SAINT $^{4}$ on 9948 reflections, $12 \%$ of the observed reflections. Data reduction, scaling and absorption corrections were performed using SAINT ${ }^{4}$ and SADABS-2014/5 was used for absorption correction. ${ }^{5}$ $w R_{2}$ (int) was 0.0628 before and 0.0441 after correction. The ratio of minimum to maximum transmission is 0.9188 . The final completeness is $100.0 \%$ out to $31.50^{\circ}$ in $Q$. The absorption coefficient $(m)$ of this material is $0.480 \mathrm{~mm}^{-1}$ and the minimum and maximum transmissions are 0.6858 and 0.7464 . The structure was solved with ShelXS ${ }^{6}$ in the space group $P 2_{1} / \mathrm{n}(\# 14)$ by direct methods and using Olex $2^{7}$ as the graphical interface. The structure was refined by least squares using ShelXL. ${ }^{8}$ All non-hydrogen atoms were refined anisotropically. Hydrogen atom positions were calculated geometrically and refined using the riding model.

High Energy Resolution Fluorescence Detection X-ray Absorption Spectroscopy (HERFD-XAS). Co HERFD-XAS (Co K $\beta$-detection) data were collected at the Cornell High Energy Synchrotron Source at C-line end station. The incident X-rays were monochromated using a double $\mathrm{Si}(111)$ crystal monochromator. Emitted $\mathrm{x}$-rays were analyzed using a set of five spherically bent Si crystals (444 reflection) mounted on a Rowland circle in combination with a Pilatus Area Detector. He-filled plastic bags were 
used to displace air from the beam flight path to minimize attenuation of the fluorescence. The spectra were collected by monitoring the intensity of the $K \beta_{1,3}$ peak as a function of incident energy.

Samples were prepared as $\sim 10 \mathrm{mM}$ solutions in MiteGen MicroRT tubes and kept frozen in liquid $\mathrm{N}_{2}$ until data collection. During data collection the samples were kept at a temperature of $\sim 170 \mathrm{~K}$ using a stream of cold $\mathrm{N}_{2}$ gas. Temperature was monitored with a diode at the base of the sample holder.

Experimental spectra were averaged and normalized using PyMCA. CoO was used as a calibrant, adjusting the energy axis to the reported values. Peaks were fit to the experimental spectra using the BlueprintXAS Matlab software package developed by Mario Delgado. ${ }^{9}$

DFT calculations were performed using the ORCA 3.00 software package. ${ }^{10}$ All spectra were calculated from geometry-optimized coordinates. Optimizations were carried out with the BP86 functional, ${ }^{11}$ zeroth order regular approximation (ZORA) for relativistic effects, ${ }^{12}$ and the scalar-relativistically recontracted def2-TZVP(-f) basis set. ${ }^{13}$ Solvation was modeled using the conductor like screening model (COSMO). ${ }^{14}$ XAS spectra were predicted using a TD-DFT approach as described previously. ${ }^{15}$ Spectral predictions were done using the B3LYP functional. ${ }^{16}$ The $\mathrm{CP}(\mathrm{PPP})$ basis set was used for Co with an integration accuracy of 7. The TZVP basis set was used for all other atoms. Solvation was again modeled using an appropriate COSMO correction.

DFT Computational Details. Three compounds $[\mathrm{Co}(\mathrm{L})(\mathrm{CN})]^{2-}[2]^{2-},\left[\mathrm{Co}(\mathrm{L})\left(\mathrm{O}_{2}\right)\right]^{-}$where $\mathrm{O}_{2}$ is bound end-on $[3]^{1-}$, and $\left[\mathrm{Co}(\mathrm{L})\left(\mathrm{O}_{2}\right)\right]^{-}$where $\mathrm{O}_{2}$ is bound side-on $[3 \mathbf{b}]^{1-}$, were 
investigated using spin-unrestricted DFT methods. All calculations were carried out with the Orca 2.9.1 program package using spin-unrestricted DFT methods. ${ }^{10}[2]^{2-},[3]^{1-}$, and $[3 \mathbf{b}]^{1-}$ were optimized in both the doublet and quartet spin states. For $[\mathbf{2}]^{2-}$, the input geometry was obtained from crystallographic data and geometry optimizations were run using the B3LYP functional ${ }^{16}$ with the triple- $\zeta$ Default-3 (TZV on hydrogen, TZVP on main-group atoms, TZVPPP on transition metal) basis set. ${ }^{17}$ Optimizations also included the diffuse basis set Diff aug_cc_VDZ_H, ${ }^{18}$ increased integration grid (Grid4), tight optimization, tight SCF convergence criteria, the RIJCOSX approximation, ${ }^{19}$ and an appropriate $^{20}$ auxiliary basis set.

The input geometry for $[3]^{1-}$ was obtained from the crystallographic data for $[2]^{2-}$ but the carbon and nitrogen atoms of the cyano ligand were exchanged for two oxygen atoms. Multiple geometry inputs for $[\mathbf{3 b}]^{1-}$ were performed in the same manner, with the additional step of manually placing the oxygen atoms in a side-on configuration; the geometry that gave the lowest overall energy as calculated by the single-point calculation was used going forward. All geometries were verified as potential energy minima by numerical frequency calculations to not contain any negative frequencies. Unrestricted natural orbitals (UNOs) were used to study and plot the electronic structure of [2] $]^{2-}$, and a combination of unrestricted corresponding orbitals (UCOs) ${ }^{21}$ and spinup/spin-down orbitals were used for $[3]^{1-}$ and $[3 \mathbf{b}]^{1-}$ due to the spin-coupling that exists in the frontier orbitals of these complexes that does not exist in [2] ${ }^{2-}$. All images were generated used the UCSF Chimera package. ${ }^{22}$ The Avogadro program ${ }^{23}$ was used to edit the $\mathrm{XYZ}$ files for converting $[2]^{2-}$ to $[3]^{1-}$ and $[3 \mathbf{b}]^{1-}$. 
SORCI Computational Details. Multireference character in the ground state of $[3]^{1-}$ was assessed with $\mathrm{SORCl}^{24}$ calculations. SORCI was performed on a complete active space (CAS) for [3 $]^{1-}$ comprising 17 electrons and 11 orbitals [CAS $\left.(17,11)\right]$. The def2-TZVP(-f)-ZORA was used on all atoms, and relativistic effects were modeled using the ZORA relativistic correction. As described elsewhere,${ }^{24}$ individual selection was used to ease the computational burden. The size of the first-order interacting space was reduced with a threshold: $T_{s e l}=10^{-6} E_{h}$. A further approximation involved reducing the reference space through another selection: all initial references that contributed less than a second threshold $\left(T_{\text {pre }}=10^{-5}\right)$ to the zeroth-order states were rejected from the reference space. Starting orbitals were taken from localized, quasi-restricted orbitals. ${ }^{25}$

Synthesis of $\left(\mathrm{Et}_{4} \mathrm{~N}\right)_{2}$ [2]: Under an inert atmosphere, a $20 \mathrm{~mL}$ scintillation vial was charged with $\left(\mathrm{Et}_{4} \mathrm{~N}\right)_{2}[1](0.120 \mathrm{~g}, 0.114 \mathrm{mmol})$, a stir bar, and $10 \mathrm{~mL}$ of $\mathrm{CH}_{3} \mathrm{CN}$. To this homogenous dark green solution, $\left[\mathrm{Et}_{4} \mathrm{~N}\right] \mathrm{CN}(0.229 \mathrm{mmol}, 0.359 \mathrm{~g})$ was added as a solid and the dark green solution immediately changed to a deep burgundy color. The resulting homogenous solution was concentrated to dryness under reduced pressure to yield a dark burgundy solid. The solid was extracted into a $\mathrm{CH}_{3} \mathrm{CN}$ and filtered through a plug of Celite ${ }^{\circledR}$. Slow diffusion of diethyl ether into the burgundy filtrate yielded needleand blocked-shaped dark burgundy crystals of the product $(109 \mathrm{mg})$. This product oxidizes readily in air. ${ }^{1} \mathrm{H} N M R\left(\delta, \mathrm{CD}_{3} \mathrm{CN}, 400 \mathrm{MHz}\right)$ : (ppm) -30.80 (s), -46.55 (s), 37.18 (s), -31.30 (s), -2.744 (s), 26.91 (s), 37.06 (s), 47.04 (s), 60.58 (s). FTIR (KBr, cm $\left.{ }^{1}\right): v(\mathrm{CO})$ 1663, $v(\mathrm{CN})$ 2109. UV-Vis: $\lambda_{\max }, \mathrm{nm}\left(\varepsilon, \mathrm{M}^{-1} \mathrm{~cm}^{-1}\right)\left(\mathrm{CH}_{3} \mathrm{CN}\right): 502$ (1070), 740 
(390). HRESI-MS: for [2] ${ }^{2-}$ : Calcd $(\mathrm{m} / \mathrm{z}): 421.1075$, Found 421.1096. Anal. Calcd for $\mathrm{C}_{37} \mathrm{H}_{62} \mathrm{CoN}_{6} \mathrm{O}_{2}$ : C, 65.17; H, 9.17; N, 12.33. Found: C, 65.09; H, 8.90; 12.17.

Gas uptake experiments with $\left(\mathrm{Et}_{4} \mathrm{~N}\right)_{2}[1]$. To determine the stoichiometry of dioxygen binding, a gas uptake experiment was conducted following a previously described manometric method using equipment described by Sorrell et al. ${ }^{26}$ Under an inert atmosphere at $21^{\circ} \mathrm{C}$, a $50 \mathrm{~mL}$ round bottom Schlenk flask was charged with a stir bar, $\left(\mathrm{Et}_{4} \mathrm{~N}\right)_{2}[1](0.500 \mathrm{~g}, 0.4760 \mathrm{mmol})$, and $25.0 \mathrm{~mL}$ of $\mathrm{CH}_{3} \mathrm{CN}$. Once the cobalt complex was completely dissolved to form a deep green homogeneous solution, the flask was fitted with a septum, sealed, and removed from the dry box. The Schlenk flask was first connected to a Schlenk line and then connected to the manometric setup under a positive flow of nitrogen gas. Purified $\mathrm{O}_{2}$ gas from the monometric glassware was then introduced to the flask through the septum. An immediate color change from deep green to dark burgundy took place within minutes ( $4 \mathrm{~min})$. The system was allowed to equilibrate and the amount of $\mathrm{O}_{2}$ that was taken up during the reaction was measured directly from the displacement of the volume change of the manometer $(23.25 \mathrm{~mL}$, $0.963 \mathrm{mmol} \mathrm{O}_{2}$ ).

Preparation of $\left(\mathrm{Et}_{4} \mathrm{~N}\right)[3]$. Typical Procedure for reaction of $\left(E t_{4} N\right)_{2}[\mathbf{1}] .+2.0$ equivalents of $\mathrm{O}_{2}(\mathrm{~g})$ : Under an inert atmosphere, a $25 \mathrm{~mL}$ round bottom Schlenk flask was charged with a stir bar, $\left(\mathrm{Et}_{4} \mathrm{~N}\right)_{2}[1](0.200 \mathrm{~g}, 0.1904 \mathrm{mmol})$, and $10 \mathrm{~mL}$ of $\mathrm{CH}_{3} \mathrm{CN}$. The cobalt complex was stirred for approximately 10 minutes until completely dissolved. The flask was fitted with a septum and sealed, and removed from the dry box. While stirring at 
room temperature, $\mathrm{O}_{2}$ gas $(9.30 \mathrm{~mL}, 0.3808 \mathrm{mmol})$ was injected to the flask via a gastight, gas transfer syringe (inserted through the septum). The color of the solution changed from deep green to deep burgundy within minutes ( 4 min). After stirring for 12 hours, the solvent was removed under vacuum, and the resulting solid was brought back into the dry box. The solid was washed with $\mathrm{Et}_{2} \mathrm{O}(3 \times 3 \mathrm{~mL})$ and the crude solid was collected on a frit. $\lambda_{\max }\left(\mathrm{CH}_{3} \mathrm{CN}\right): 390 \mathrm{~nm}, 500 \mathrm{~nm}$, and $785 \mathrm{~nm}$. $\mu_{\text {eff }}=2.13 \mu_{\mathrm{B}}$ (Evan's Method, $\mathrm{CH}_{3} \mathrm{CN}, 298 \mathrm{~K}$ ). Combustion analysis studies were conducted on [3] ${ }^{1-}$ as its potassium salt. The potassium salt of $[3]^{1-}$ was isolated by reacting $\mathrm{K}_{2}[1]$ with dioxygen as described above for the $\mathrm{Et}_{4} \mathrm{~N}^{+}$salt. This potassium complex (K[3]) displays similar spectroscopic signatures to those of the $\mathrm{Et}_{4} \mathrm{~N}[3]$ salt but it far less soluble in organic solvents. Anal. Calcd for $\mathrm{K}[3] \cdot 0.5\left(\mathrm{Et}_{2} \mathrm{O}\right) \cdot 0.5\left(\mathrm{CH}_{3} \mathrm{CN}\right): \mathrm{C}_{23} \mathrm{H}_{28.5} \mathrm{CoKN}_{3.5} \mathrm{O}_{4.5}: \mathrm{C}$ 52.73, H 5.44, N 9.36. Found: C 52.56, H 5.81, N 9.42.

The final product of the oxygenation reaction is stable in acetonitrile for days. The product is stable in chlorinated solvents $\left(\mathrm{CH}_{2} \mathrm{Cl}_{2}\right)$ for up to $12 \mathrm{hrs}$. The complex is also stable to vacuum and does not dissociate oxygen in solution when the solution is sparged with $\mathrm{Ar}$ or $\mathrm{N}_{2}$ gas as evidenced by UV-vis absorption spectroscopy. The oxygenation reaction of $\left(\mathrm{Et}_{4} \mathrm{~N}\right)_{2}[1]$ can be followed directly by UV-visible absorption spectroscopy as shown in Figure S4. During the oxygenation reaction, we observe an intermediate species (orange trace below) grow in that eventually fades to form the final stable species $\left(\mathrm{Et}_{4} \mathrm{~N}\right)[3]$, represented in the burgundy trace below.

Stoichiometric Reaction of $\left(\mathrm{Et}_{4} \mathrm{~N}\right)[3]$ with $\mathrm{PPh}_{3}$ : Under an inert atmosphere, a $25 \mathrm{~mL}$ round bottom Schlenk flask was charged with a stir bar, $\left(\mathrm{Et}_{4} \mathrm{~N}\right)_{2}[1](0.150 \mathrm{~g}, 0.143$ 
mmol), and $10 \mathrm{~mL}$ of $\mathrm{CH}_{3} \mathrm{CN}$. Once the solution was homogeneous, the flask was fitted with a septum, sealed and removed from the dry box. While stirring at room temperature, $\mathrm{O}_{2}$ gas $(7.00 \mathrm{~mL}, 0.143 \mathrm{mmol}$ at $1 \mathrm{~atm})$ was injected to the flask via a gastransfer syringe (inserted through the septum). The solution color changed from deep green to deep burgundy within minutes ( $4 \mathrm{~min})$. After stirring for 12 hours, the solvent was removed under vacuum, and the resulting burgundy solid was brought back into the dry box. Triphenylphosphine $\left(\mathrm{PPh}_{3}\right)(0.150 \mathrm{~g}, 0.572 \mathrm{mmol})$ in $3 \mathrm{~mL}$ of $\mathrm{CH}_{3} \mathrm{CN}$ was added to the dark burgundy solid. The solution was stirred for 4 hours. Over this time interval the color of the reaction mixture changed from deep burgundy to deep green. Solvent was removed under vacuum. The solid that remained was extracted multiple times with diethyl ether $(4 \times 10 \mathrm{~mL})$, and the extracts were filtered through a silica plug to remove insoluble materials (i.e., cobalt complex). Evaporation of the ether yielded a solid $(0.136 \mathrm{~g})$ that was analyzed by ${ }^{1} \mathrm{H}$ and ${ }^{31} \mathrm{P}$ NMR spectroscopy $[(\delta, \mathrm{CDCl} 3,400$ $\left.\mathrm{MHz}):(\mathrm{ppm}) 24.71\left(\mathrm{~s}, \mathrm{OPPh}_{3}\right)\right]$ that showed complete conversion of the $\mathrm{PPh}_{3}$ to $\mathrm{OPPh}_{3}$ (86\% isolated yield) under these conditions.

Additional experiments indicated that $\left(\mathrm{Et}_{4} \mathrm{~N}\right)[3]$ did not have to be isolated for these stoichiometric reactions. Instead, $\left(\mathrm{Et}_{4} \mathrm{~N}\right)[3]$ could be generated in situ by the addition of dry oxygen gas to acetonitrile solutions of $\left(\mathrm{Et}_{4} \mathrm{~N}\right)_{2}[1]$ with an $\mathrm{O}_{2}(\mathrm{~g})$ to $\left(\mathrm{Et}_{4} \mathrm{~N}\right)_{2}[1]$ ratio of $2: 1$. After stirring for 30 minutes, substrate could be added directly to these reactions mixtures anaerobically as acetonitrile solutions. This procedure gives identical product yields as observed when using isolated $\left(\mathrm{Et}_{4} \mathrm{~N}\right)[3]$. 
Stoichiometric Reaction of $\left(\mathrm{Et}_{4} \mathrm{~N}\right)$ [3] with 2-PPA: Under an inert atmosphere, a 25 $\mathrm{mL}$ round bottom Schlenk flask was charged with a stir bar, $\left(\mathrm{Et}_{4} \mathrm{~N}\right)_{2}[1](0.046 \mathrm{~g}, 0.0438$ $\mathrm{mmol}$ ), and $6 \mathrm{~mL}$ of $\mathrm{CH}_{3} \mathrm{CN}$. Once the solution was homogeneous, the flask was fitted with a septum, sealed and removed from the dry box. While stirring at room temperature, $\mathrm{O}_{2}$ gas $(2.20 \mathrm{~mL}, 0.090 \mathrm{mmol}$ at $1 \mathrm{~atm})$ was injected to the flask using a gas-tight syringe and injecting through the septum. The solution color changed from deep green to deep burgundy almost immediately. The reaction mixture was allowed to stir for 2 hours and then 2-phenylpropionaldehyde $(0.0120 \mathrm{~g}, 0.0896 \mathrm{mmol})$ was added to the reaction mixture as an acetonitrile solution $(1 \mathrm{~mL})$. The reaction was stirred for four hours and then concentrated under vacuum to yield a brownish solid. The resulting solid was extracted 3 times with a 1:1 hexanes/ethyl acetate solution and the extract filtered through a plug of silica gel to remove insoluble materials (i.e. cobalt complex). The filtrate was analyzed by GC and indicated that approximately $85 \%$ of the 2-PPA had been converted to acetophenone.

Catalytic Deformylation of 2-phenylpropionaldehyde (2-PPA) by $\left(\mathrm{Et}_{4} \mathrm{~N}\right)_{2}[1]$.

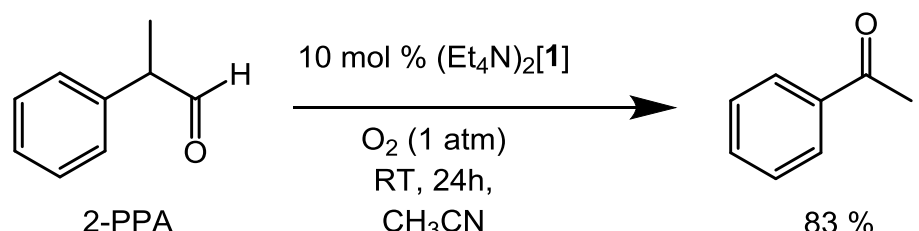

Typical procedure for catalytic 2-PPA oxidation: The reaction was set up in a drybox under an inert atmosphere using freshly distilled 2-PPA purchased from Sigma-Aldrich. $\left(\mathrm{Et}_{4} \mathrm{~N}\right)_{2}[1]$ (0.200 mg, $0.1904 \mathrm{mmol}$ ), 2-PPA (255 $\mu \mathrm{L}, 1.904 \mathrm{mmol}$ ), and $20 \mathrm{~mL}$ of $\mathrm{CH}_{3} \mathrm{CN}$ were added to a $50 \mathrm{~mL}$ round bottom flask that was charged with a stir bar and sealed with a septum. 
The flask was removed from the drybox and, while stirring, gently sparged with dry dioxygen gas. After 24 hours, the reaction was removed from the $\mathrm{O}_{2}$ gas line and the acetonitrile was removed using a rotary evaporator to yield a thick reddish-brown residue. This residue was further dried on a vacuum line (30 minutes). The residue was then taken up in $20 \mathrm{~mL}$ of a 9:1 hexanes/ethyl acetate solution and passed through a plug of silica gel to remove the catalyst. The colorless filtrate was then concentrated again using a rotary evaporator and acetophenone was isolated as the organic product as a clear oily-liquid ( $83 \%$ isolated yield, $190 \mathrm{mg}$ ). The acetophenone product was characterized by ${ }^{1} \mathrm{H}$ NMR spectroscopy and GC analysis and compared with a pure sample from commercial vendors. The other products of this reaction (i.e., formate or formic acid) were not isolated. 


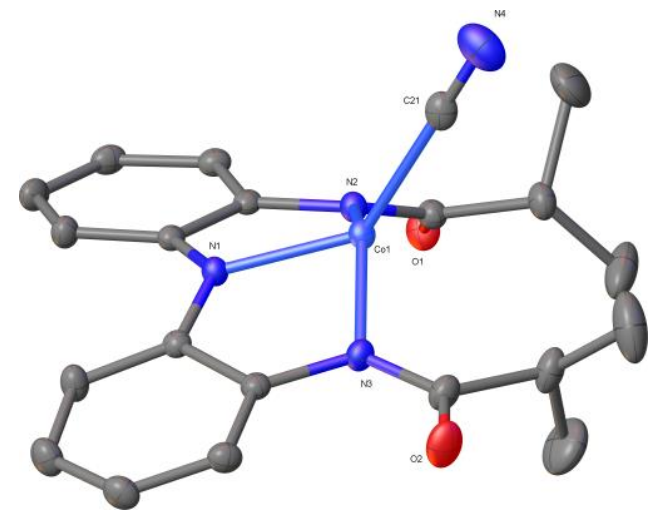

Figure S1: Plot of $\left[\mathrm{Et}_{4} \mathrm{~N}\right]_{2}[2]$ with counter cations and $\mathrm{H}$ atoms omitted for clarity. 

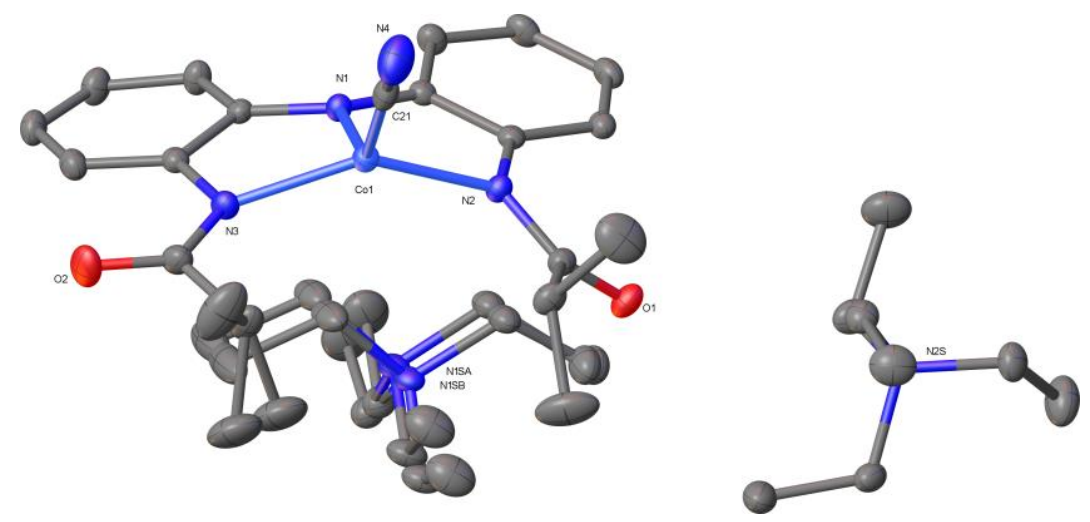

Figure S2: Plot of the asymmetric unit of $\left[\mathrm{Et}_{4} \mathrm{~N}\right]_{2}[2]$ showing two disordered components. $\mathrm{H}$ atoms omitted for clarity. 


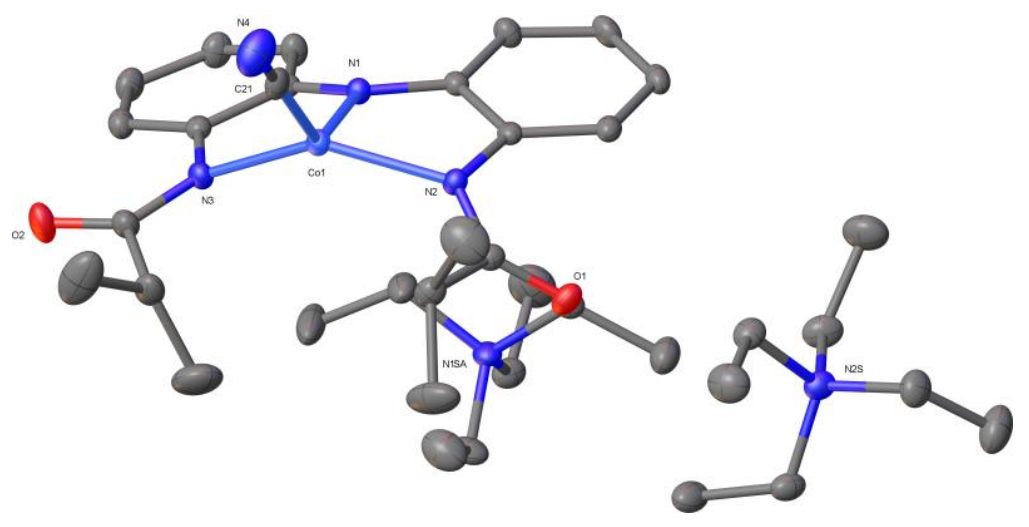

Figure S3: Plot of the asymmetric unit of $\left[\mathrm{Et}_{4} \mathrm{~N}_{2}[2]\right.$ with one of the two disorder components. $\mathrm{H}$ atoms omitted for clarity. 


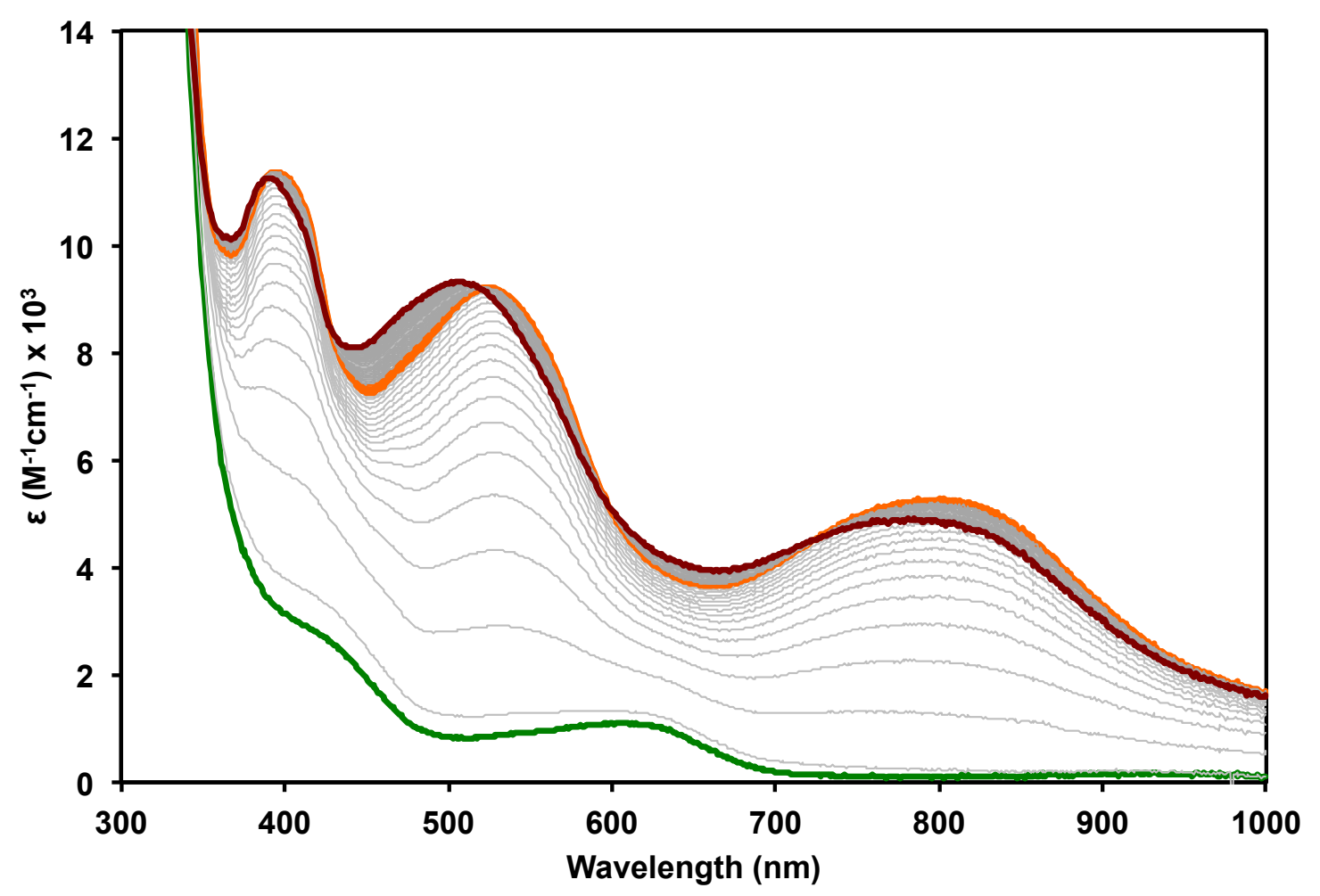

Figure S4. UV-visible absorption spectrum of $\left(\mathrm{Et}_{4} \mathrm{~N}\right)_{2}[1]$, (green trace, prior to oxygenation) upon addition of dioxygen into the headspace above a solution of $\left(\mathrm{Et}_{4} \mathrm{~N}\right)_{2}[1]$ in $\mathrm{CH}_{3} \mathrm{CN}$ at $25^{\circ} \mathrm{C}$. Scan rate of $1 \mathrm{scan} / \mathrm{min}$. Orange trace corresponds to a short-lived intermediate and burgundy trace corresponds to the final oxygenated species $\left(\mathrm{Et}_{4} \mathrm{~N}\right)[3]$ upon reaction with dioxygen. 


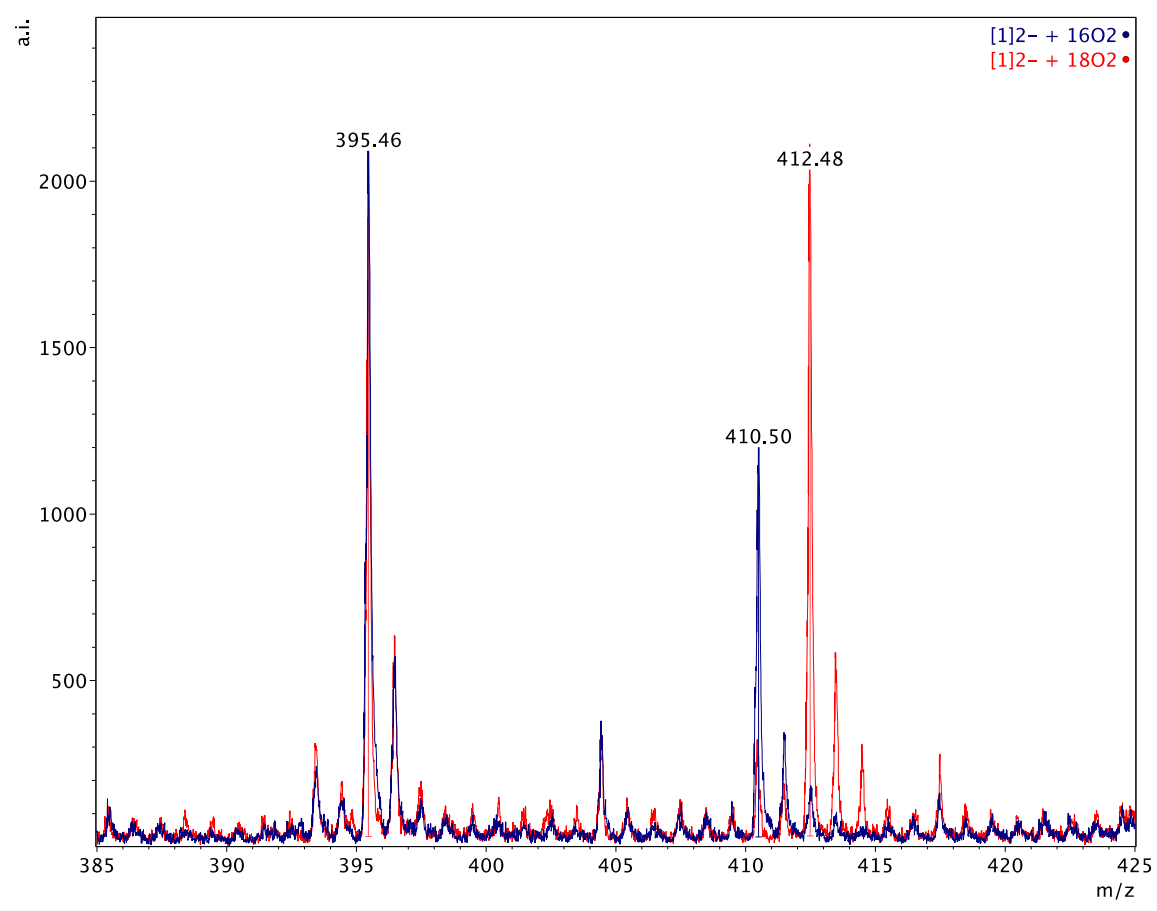

Figure S5. MALDI-TOF mass spectra for $\left[\mathrm{Et}_{4} \mathrm{~N}\right]\left[{ }^{16 / 18} 3\right]$, resulting from reaction of $\left[\mathrm{Et}_{4} \mathrm{~N}\right]_{2}[1]$ with 2 equivalents of ${ }^{16} \mathrm{O}_{2}$ (blue) or ${ }^{18} \mathrm{O}_{2}$ (red). Masses correspond to $\mathrm{L}+\mathrm{Co}$ $(m / z=395.46), L+C o+{ }^{16} \mathrm{O}(m / z=410.50)$, and $\mathrm{L}+\mathrm{Co}+{ }^{18} \mathrm{O}(\mathrm{m} / \mathrm{z}=412.48)$. 


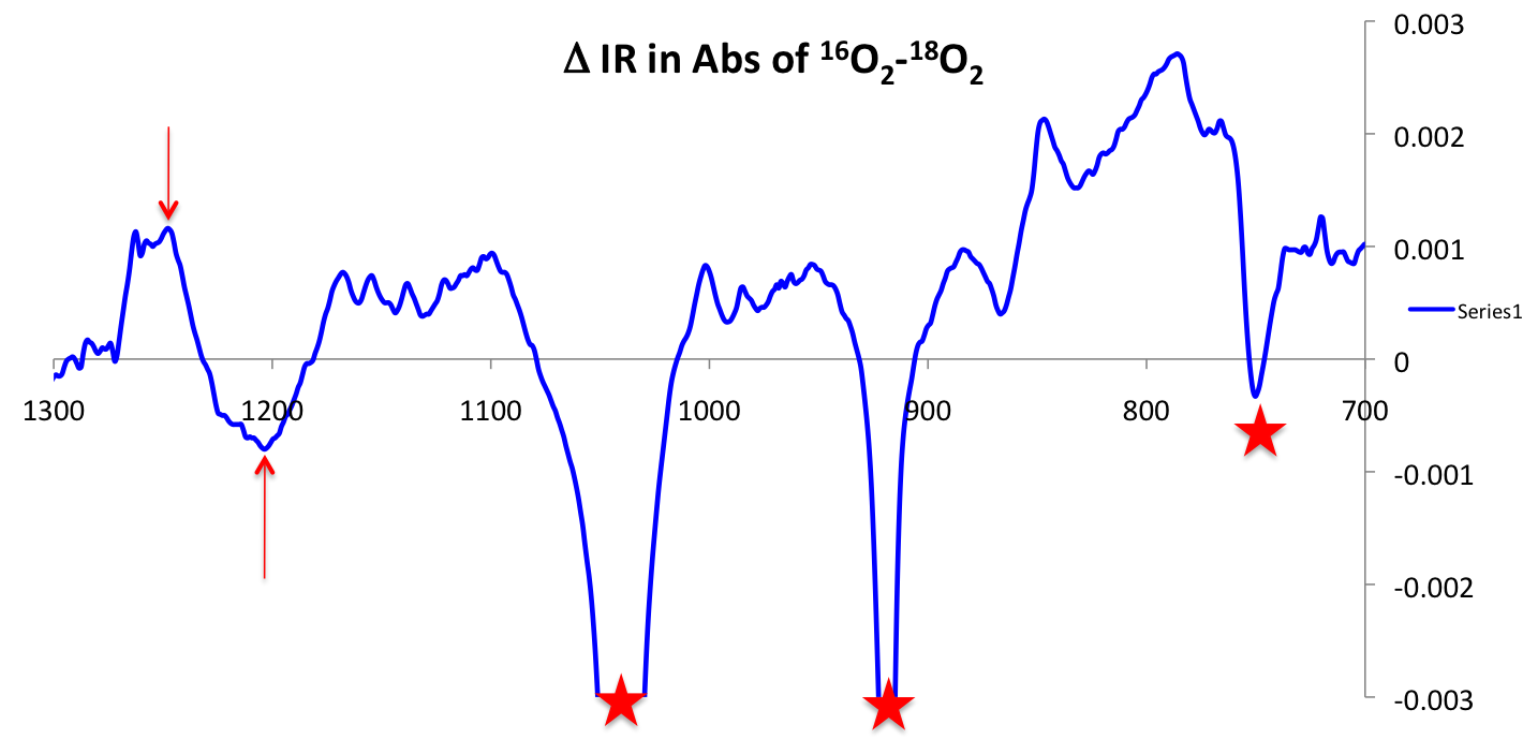

Figure S6. Liquid-cell IR difference spectrum, which shows $\mathrm{O}_{2}$ vibrational shift from $1248 \mathrm{~cm}^{-1}$ to $1203 \mathrm{~cm}^{-1}$ (arrows) upon isotopic labeling of [ $\left.\mathrm{Et}_{4} \mathrm{~N}\right][3]$. Stars indicate residual acetonitrile solvent peaks. 


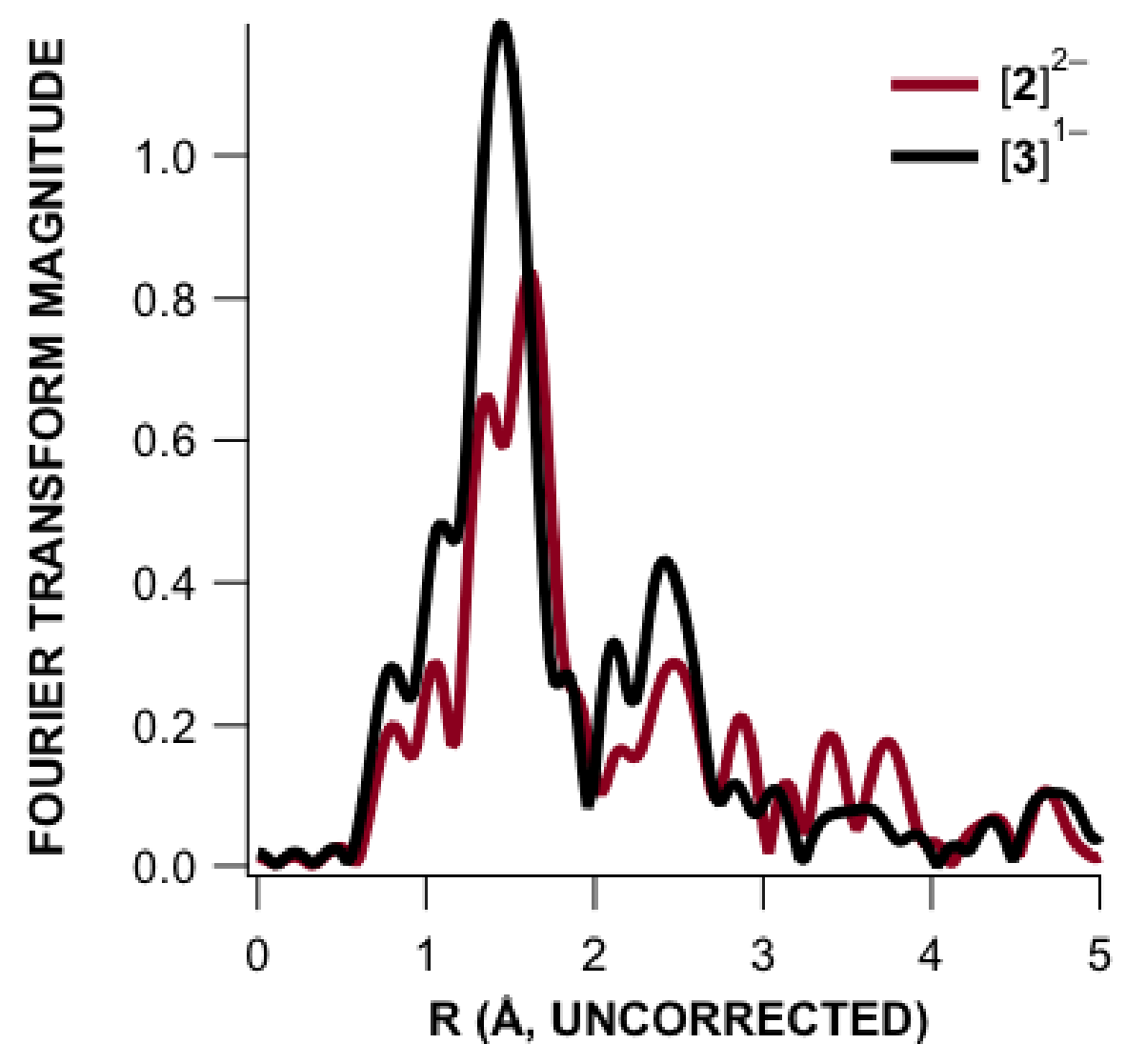

Figure S7. Overlay of Fourier-transformed EXAFS for $[2]^{2-}$ and $[3]^{1-}$. The Fourier transform amplitude of [3] ${ }^{1-}$ is larger than that of [2] ${ }^{2-}$ due to the proximity of the distal $O$ atom in bent, end-on $\mathrm{O}_{2}^{-}$coordination. 

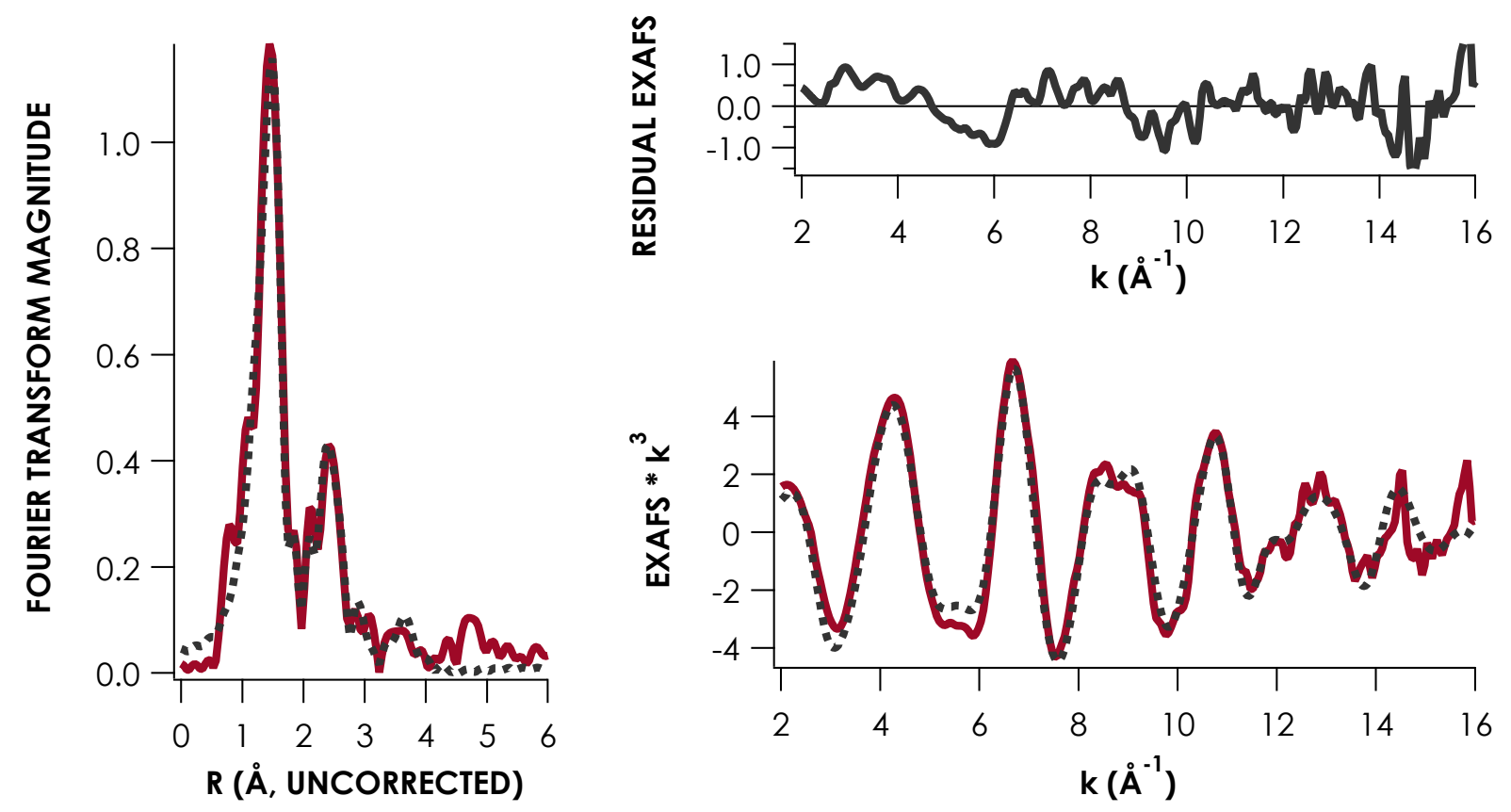

Figure S8. EXAFS and fits for $[3]^{1-}$. Experimental data are red, fits are dashed black. Inclusion of paths to model Co-C(isopropyl) scatter in both [2] ${ }^{2-}$ and $[3]^{1-}$ improve fit quality. Similarity in extracted distances suggest that $L$ binding is not significantly perturbed on going from the $\mathrm{CN}^{-}$to the $\mathrm{O}_{2}$ adducts, also in accord with calculated structures. 
Table S1. EXAFS Fitting Parameters

\begin{tabular}{|c|c|c|c|c|c|c|c|c|}
\hline & Path & $\mathrm{CN}^{\mathrm{a}}$ & $\mathbf{R}(\AA)$ & $\Delta \mathbf{R}(\mathbf{A})$ & $\sigma\left(\AA^{2}\right)^{b}$ & $\Delta \sigma\left(\AA^{2}\right)^{b}$ & $E_{0}(e V)$ & $F(\%)^{c}$ \\
\hline \multirow[t]{8}{*}[2]{$^{2-}$} & Co-N/C & 4 & 1.978 & 0.001 & 512 & 12 & 1.589 & 22.9 \\
\hline & Co-C & 2 & 2.851 & 0.011 & 385 & 102 & & \\
\hline & Co-N-C & 14 & 3.069 & 0.017 & 636 & 282 & & \\
\hline & $\mathrm{Co}-\mathrm{O} / \mathrm{C}$ & 4 & 4.323 & 0.008 & 425 & 85 & & \\
\hline & (isopropyl) & 2 & 3.299 & 0.01 & 395 & 100 & & \\
\hline & $\begin{array}{l}\text { Co-C } \\
\text { (isopropyl) }\end{array}$ & 2 & 3.961 & 0.009 & 175 & 91 & & \\
\hline & Co-C & & & & & & & \\
\hline & (isopropyl) & 2 & 4.536 & 0.011 & 35 & 90 & & \\
\hline \multirow[t]{5}{*}[3]{$^{1-}$} & Co-N/O & 4 & 1.884 & 0.001 & 515 & 11 & -4.29 & 24.41 \\
\hline & $\mathrm{Co}-\mathrm{C} / \mathrm{O}$ & 3 & 2.779 & 0.003 & 301 & 22 & & \\
\hline & $\begin{array}{l}\text { (isopropyl) } \\
\text { Co-C }\end{array}$ & 4 & 4.082 & 0.009 & 445 & 87 & & \\
\hline & (isopropyl) & 2 & 3.196 & 0.02 & 915 & 269 & & \\
\hline & (isopropyl) & 2 & 3.596 & 0.013 & 451 & 133 & & \\
\hline
\end{tabular}

${ }^{a}$ Coordination numbers $(\mathrm{CN})$ were held constant during fits. Errors in $\mathrm{CN}$ are estimated to be on the order of $25 \%$. ${ }^{b}$ Debye-Waller factors $(\sigma)$ are multiplied by $10^{5} .{ }^{c}$ Goodness of fit is measured by $F$, defined as $F=\left[\Sigma k^{6}\left(E X A F S_{\text {expt }}-E X A F S_{\text {calc }}\right)^{2} / \Sigma k^{6}\left(E X A F S_{\text {expt }}\right)^{2}\right]^{1 / 2}$. 


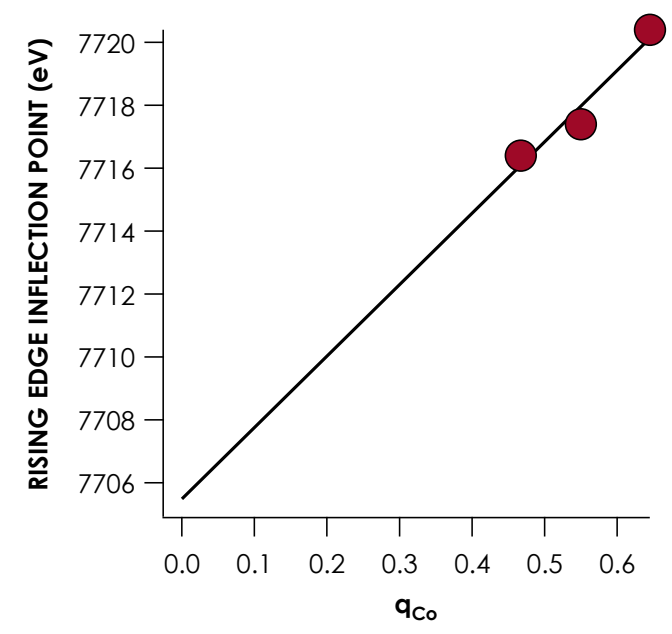

Figure S9. Experimental rising edge inflection point energies for the compounds under investigation correlate to Löwdin atomic charges for Co from B3LYP/def2-TZVP-ZORA calculations with $R^{2}=0.94$. The $y$-intercept is $7706 \pm 3 \mathrm{eV}$, consistent with the rising edge inflection point energy for Co metal which is $7709 \mathrm{eV}$. Rising edges distinguish all three compounds from one another, at $7716.4 \mathrm{eV}, 7717.4 \mathrm{eV}$, and $7720.4 \mathrm{eV}$ for [1] ${ }^{2-}$, $[2]^{2-}$, and $[3]^{1-}$, respectively. 


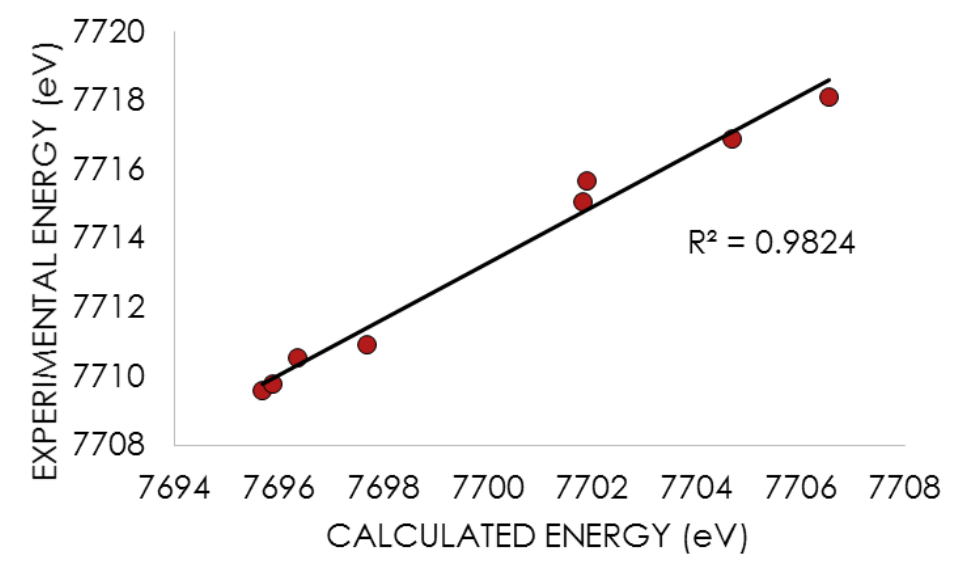

Figure S10. Correlation of experimental Co K pre-edge XAS energies to transition energies calculated by TDDFT. (B3LYP-def2-TZVP-ZORA). 

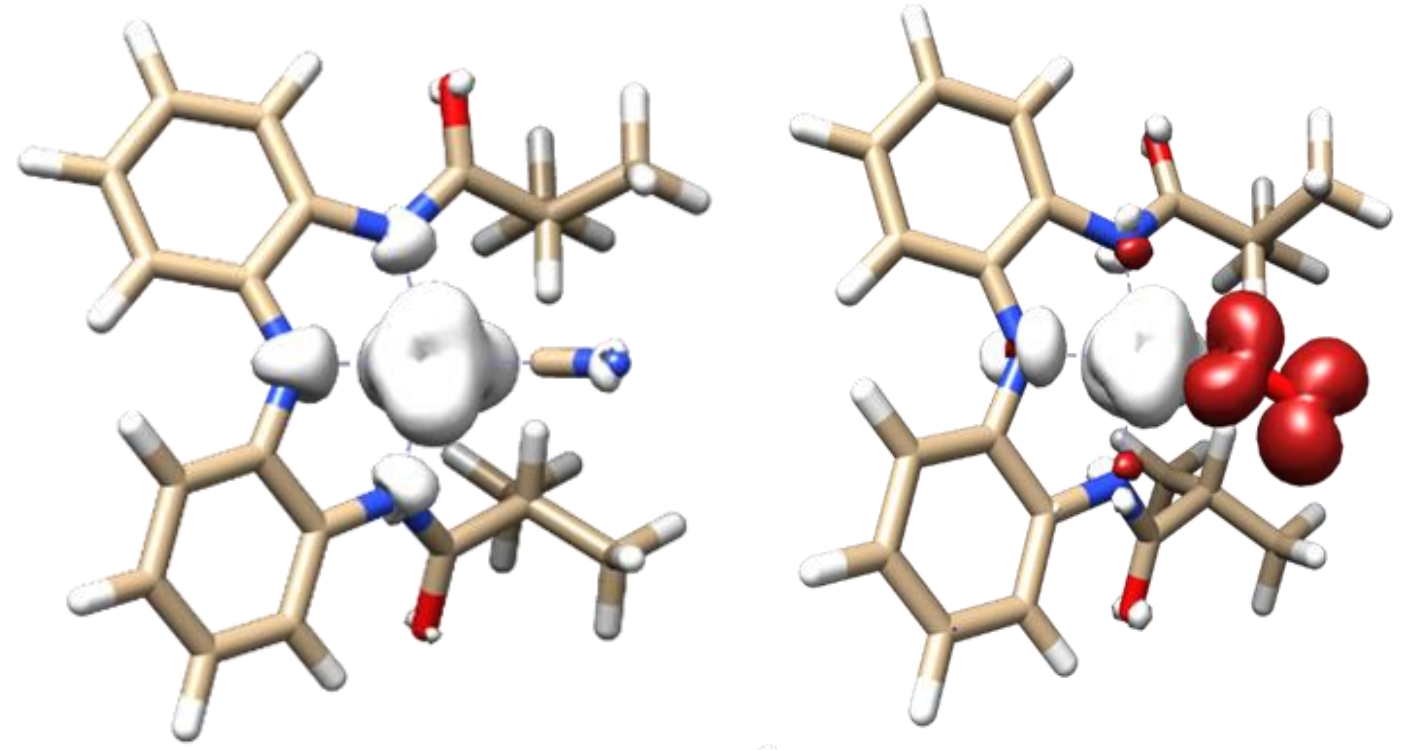

Figure S11. Spin densities of $[2]^{2-}$ (left) and [3] ${ }^{1-}$ (right). 


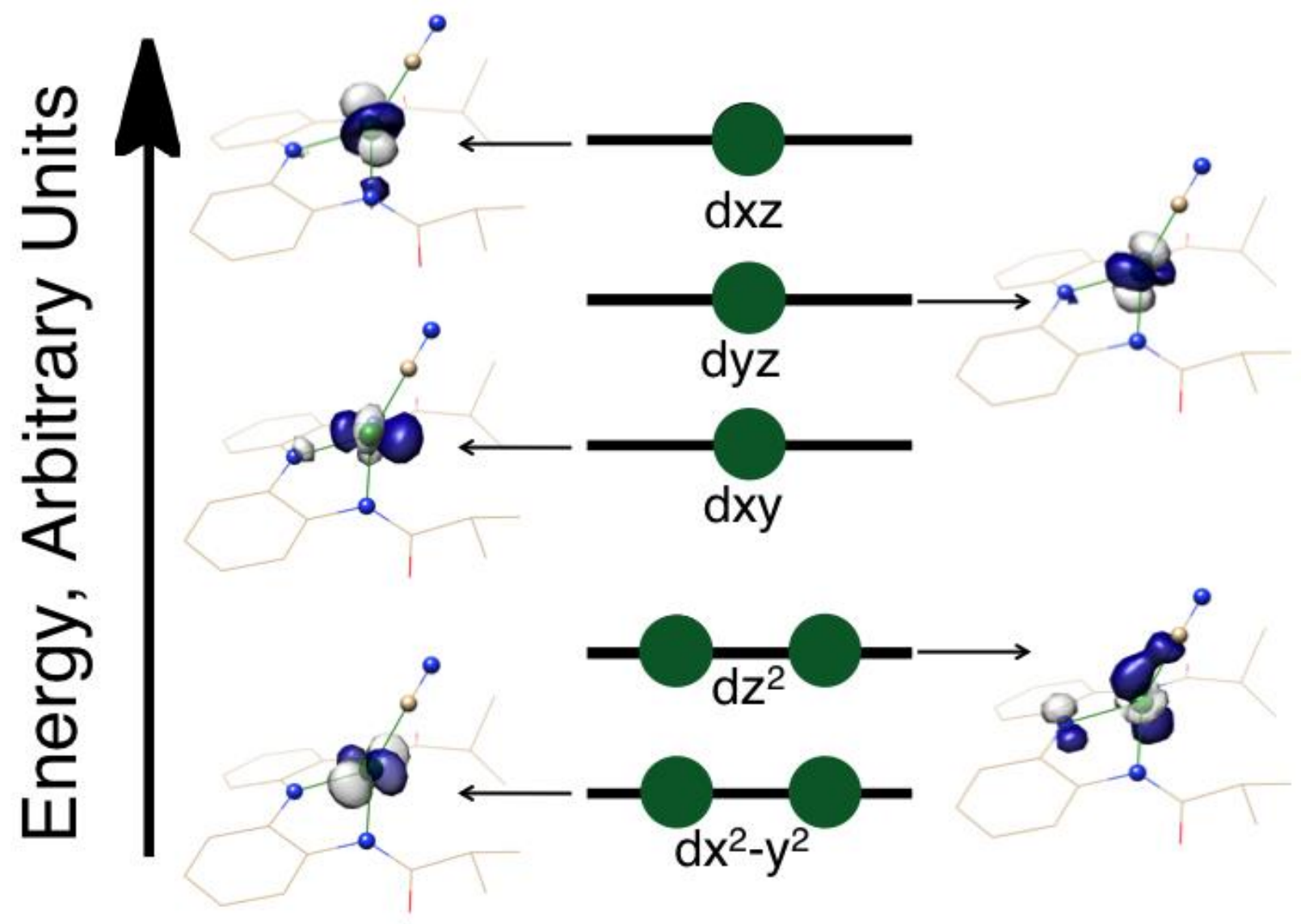

Figure S12. Molecular orbitals for [2] ${ }^{2-}$. 


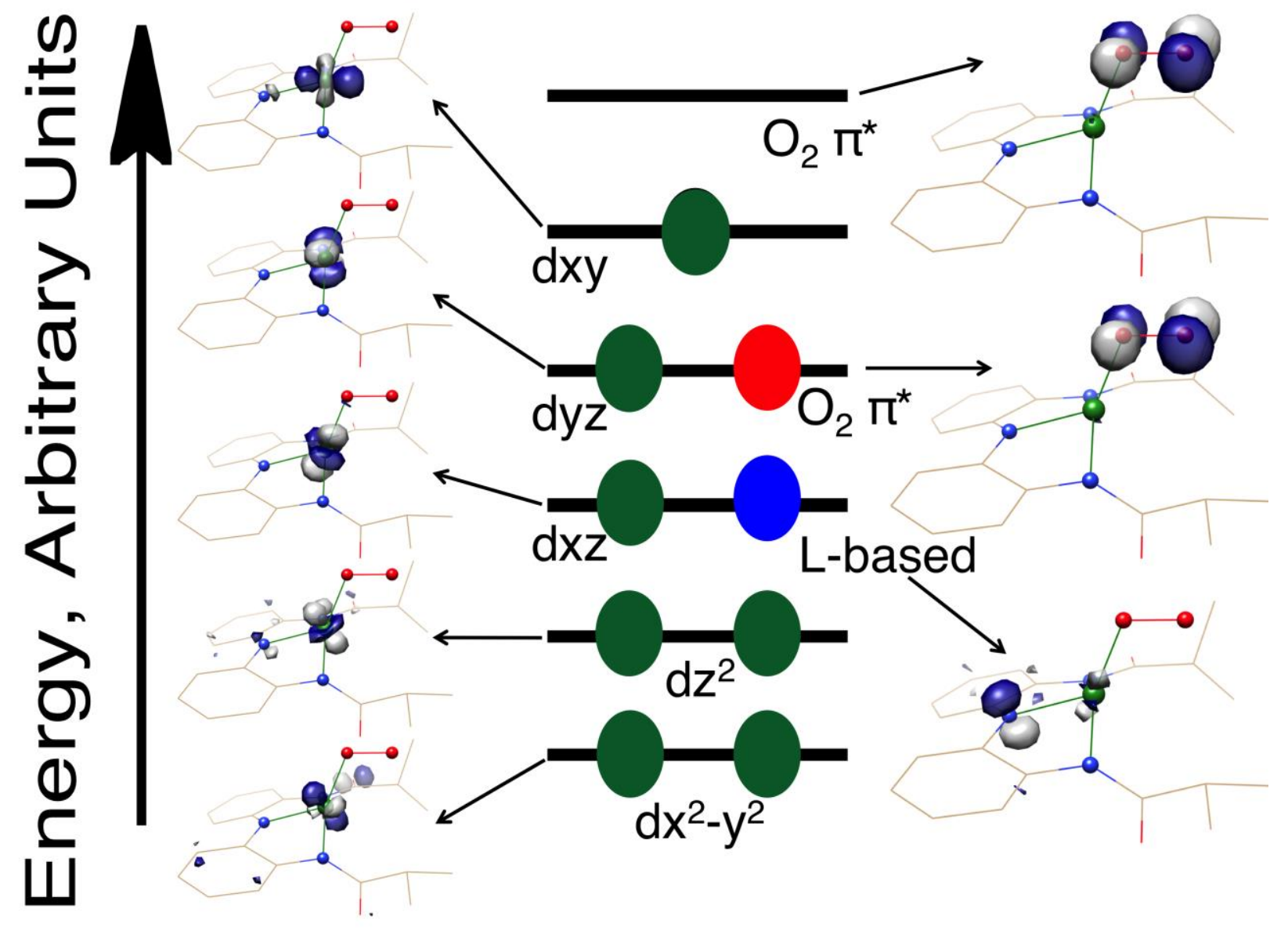

Figure S13. Molecular orbitals for [3] ${ }^{1-}$. Green dots represent Co-based electrons, while the blue and red dots represent L-based and $\mathrm{O}_{2}$-based electrons, respectively. 


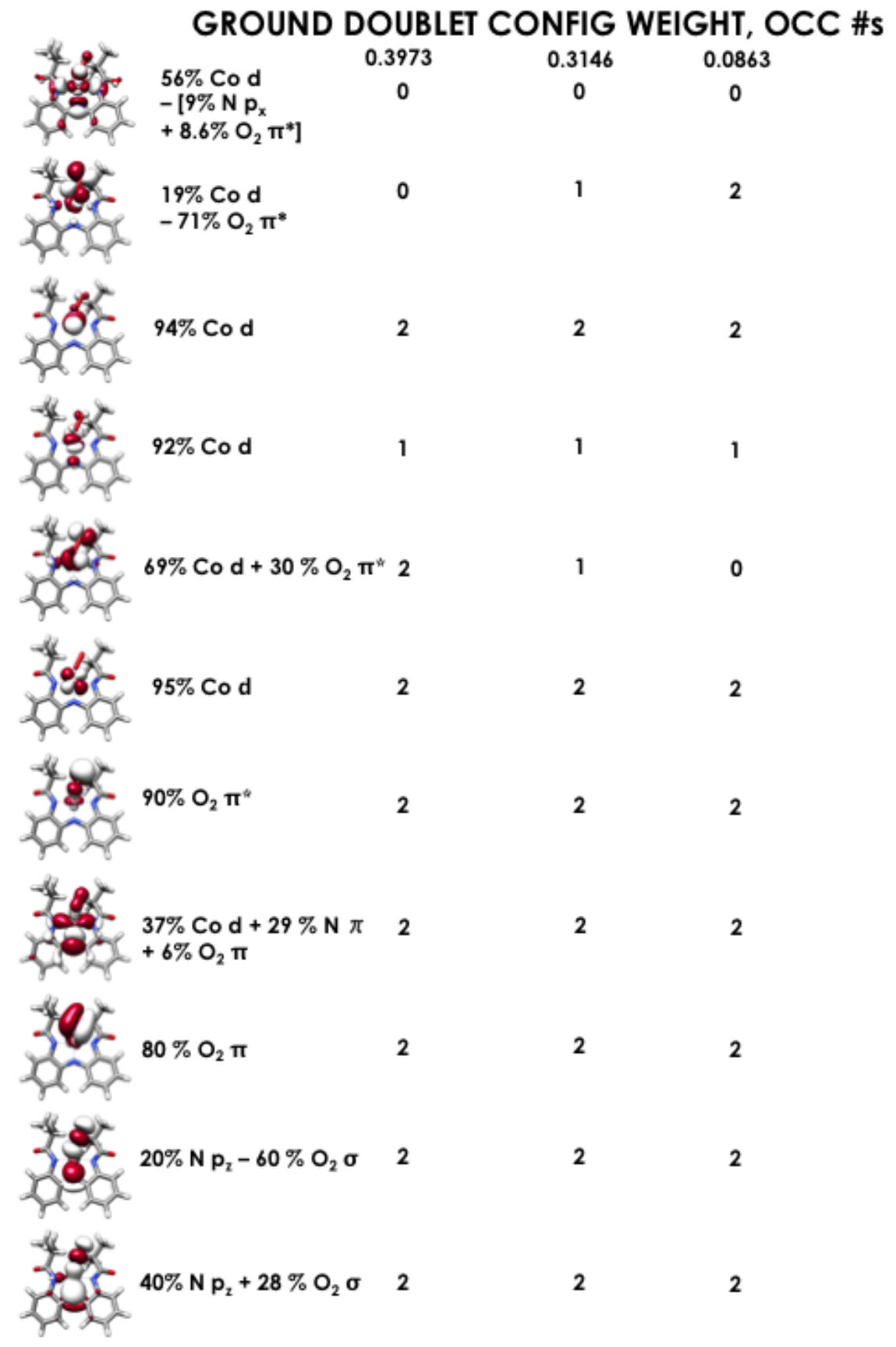

Figure S14. Natural orbitals from a SORCI calculation on $[3]^{1-}$. The weighted configurations for the lowest energy doublet state (the ground state of the ion) are shown. 


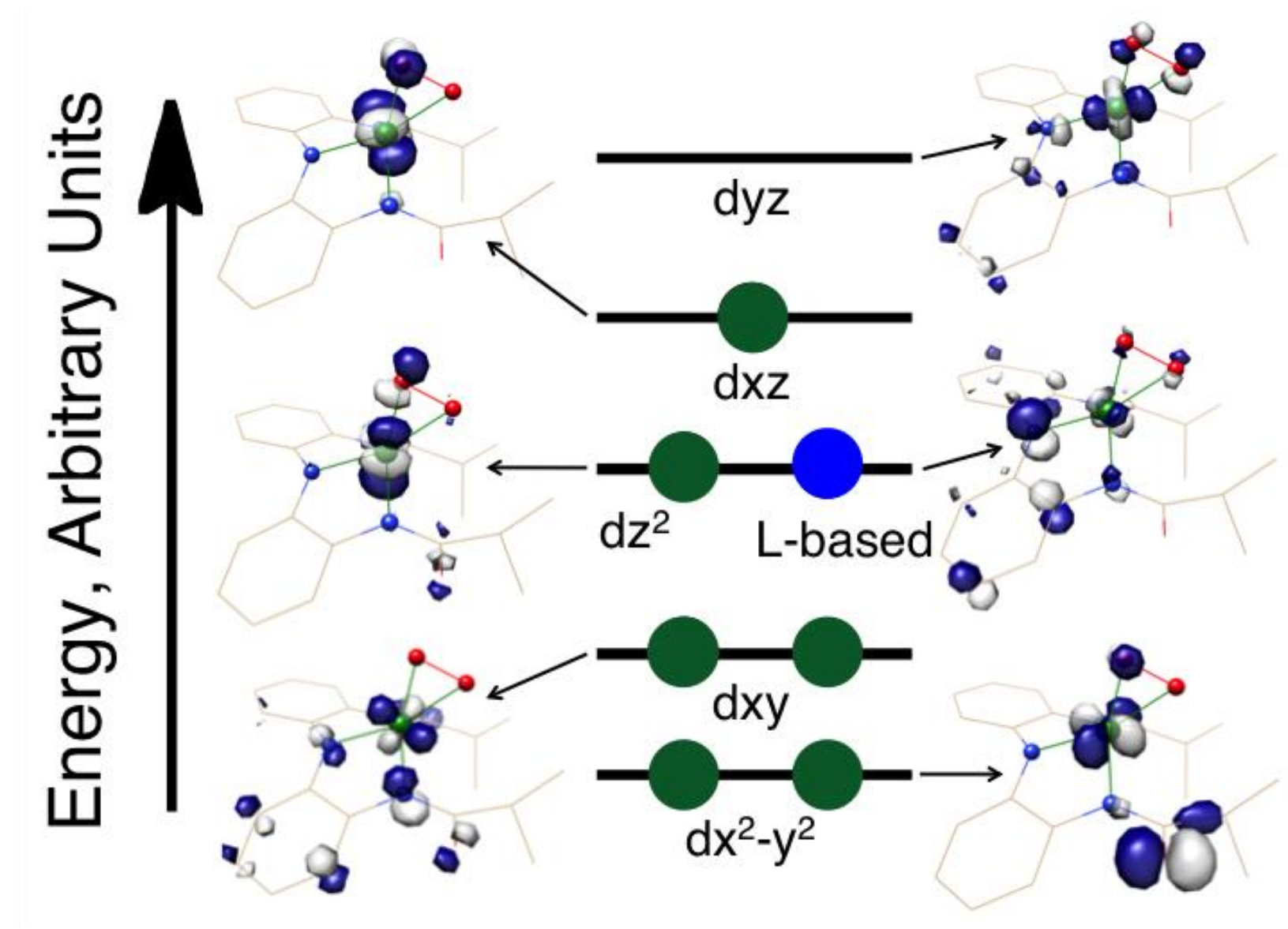

Figure S15. Molecular orbitals for $[3 \mathbf{b}]^{1-}$. Like $[3]^{1-}$, the ground state electron configuration of [3b $]^{1-}$ has one unpaired electron to give an overall spin state of $S=1 / 2$. Upon examination of the frontier orbitals, the ground state is again a spin-coupled state in which the $\mathrm{Co} \mathrm{d}_{z}{ }^{2}$ orbital antiferromagnetically couples with a ligand-based orbital. There are no unpaired electrons on the $\mathrm{O}_{2}$-ligand, and the unpaired electron resides in the Co $d_{y z}$ orbital. Therefore, $[3 b]^{1-}$ is formally a peroxide complex with an unpaired electron on the $L$ radical $(S=1 / 2$ ) that couples to an intermediate-spin Co(III) center ( $S$ $=1$ ) to form an overall $S=1 / 2$ ground state. 

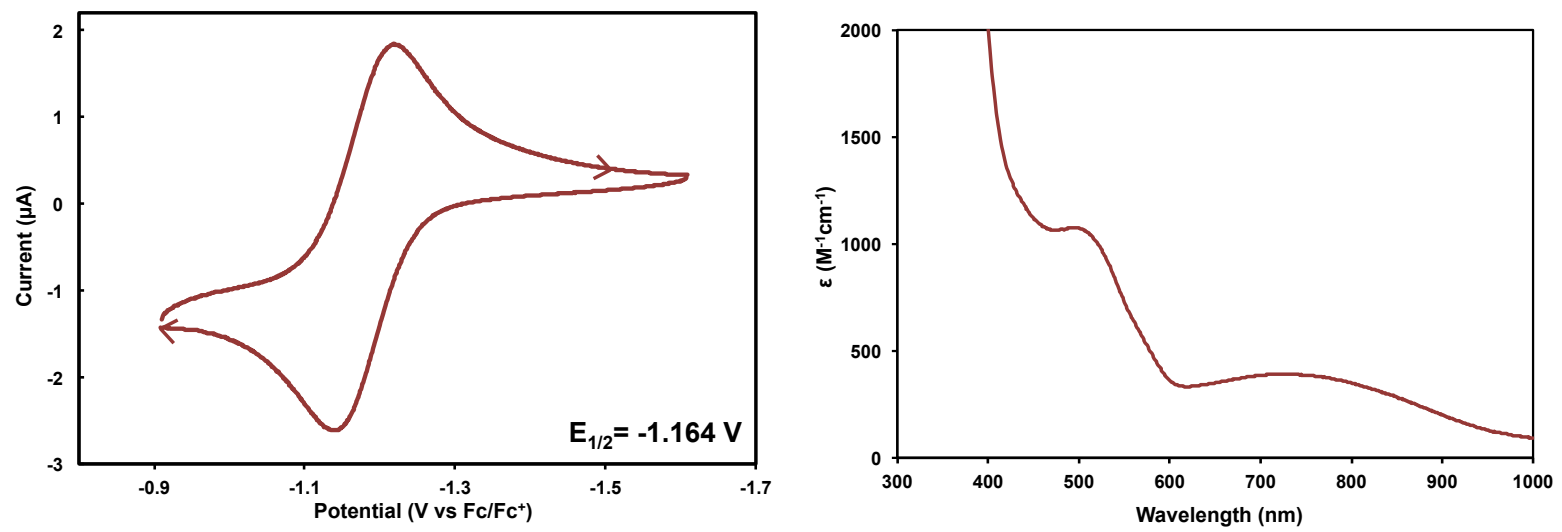

Figure S16: (Left) Cyclic voltammogram of $\left(\mathrm{Et}_{4} \mathrm{~N}\right)_{2}[2]$ scan rate of $10 \mathrm{mV} / \mathrm{s}$, with $0.1 \mathrm{M}$ TBAPF 6 in $\mathrm{CH}_{2} \mathrm{Cl}_{2}$ as the supporting electrolyte, referenced vs. $\mathrm{Fc} / \mathrm{Fc}^{+}$, with $\mathrm{Ag} / \mathrm{Ag}^{+}$as the reference electrode, using a glassy carbon working electrode. (Right) UV-visible absorption spectrum of $\left(\mathrm{Et}_{4} \mathrm{~N}\right)_{2}[2]$ recorded in acetonitrile. 
Table S2. Summary of X-ray crystallographic data for $\left[\mathrm{Et}_{4} \mathrm{~N}\right]_{2}[\mathbf{2}]$.

Compound

Formula

Formula Weight $\mathrm{g} / \mathrm{mol}$

Temperature $(\mathrm{K})$

Crystal system

Space Group

a, $\AA$

$b, \AA$

$c, \AA$

$\alpha^{\circ}$

$\beta^{\circ}$

$Y^{\circ}$

$V, \AA^{3}$

$Z$

Density (calculated)

Crystal size

Data / restraints / parameters

Goodness-of-fit on $F^{2}$

$R 1^{\mathrm{a}}, \mathrm{w} R 2^{\mathrm{b}}(k 2 \sigma(I))$

$R 1^{\mathrm{a}}$, wR ${ }^{\mathrm{b}}$ (all data)
$\left[\mathrm{Et}_{4} \mathrm{~N}\right]_{2}[2]$

$\mathrm{C}_{37} \mathrm{H}_{62} \mathrm{CoN}_{6} \mathrm{O}_{2}$

681.85

173(2)

Monoclinic

$P 2_{1} / \mathrm{n}$

11.150(5)

16.151(7)

22.24(1)

90

104.421(7)

90

$3879(3)$

4

$1.168 \mathrm{~g} / \mathrm{cm}^{3}$

$0.69 \times 0.43 \times 0.40 \mathrm{~mm}^{3}$

9540 / 88 / 466

1.075

$0.0482,0.1210$

$0.0721,0.1353$

${ }^{\mathrm{a}} R 1=\Sigma|| \mathrm{F}_{\mathrm{o}}|-| \mathrm{Fc}|| / \Sigma\left|\mathrm{F}_{\mathrm{o}}\right|{ }^{\mathrm{b}} w R 2=\left[\Sigma\left[\mathrm{w}\left(\mathrm{F}_{\mathrm{o}}{ }^{2}-\mathrm{F}_{\mathrm{c}}{ }^{2}\right)^{2}\right] / \Sigma\left[\mathrm{w}\left(\mathrm{F}_{\mathrm{o}}{ }^{2}\right)^{2}\right]\right]^{1 / 2}, w=1 / \sigma^{2}\left(\mathrm{~F}_{\mathrm{o}}{ }^{2}\right)$ $+(\mathrm{aP})^{2}+\mathrm{bP}$, where $\mathrm{P}=\left[\max \left(0\right.\right.$ or $\left.\left.\mathrm{F}_{\mathrm{o}}{ }^{2}\right)+2\left(\mathrm{~F}_{\mathrm{c}}^{2}\right)\right] / 3$. 
Table S3. Crystallographic bond lengths $(\AA)$ for $\left(E t_{4} N\right)_{2}[2]$.

\begin{tabular}{lll}
\hline Atom & Atom & Length/Å \\
\hline Co1 & N1 & $1.950(1)$ \\
Co1 & N2 & $2.010(1)$ \\
Co1 & N3 & $1.997(2)$ \\
Co1 & C21 & $2.088(2)$ \\
O1 & C7 & $1.248(2)$ \\
O2 & C17 & $1.244(2)$ \\
N1 & C1 & $1.390(2)$ \\
N1 & C11 & $1.384(2)$ \\
N2 & C6 & $1.421(2)$ \\
N2 & C7 & $1.351(2)$ \\
N3 & C16 & $1.419(2)$ \\
N3 & C17 & $1.356(2)$ \\
N4 & C21 & $1.073(3)$ \\
C1 & C2 & $1.407(2)$ \\
C1 & C6 & $1.441(2)$ \\
C2 & C3 & $1.398(2)$ \\
C3 & C4 & $1.386(3)$ \\
C4 & C5 & $1.398(2)$ \\
C5 & C6 & $1.396(2)$ \\
C7 & C8 & $1.532(2)$ \\
C8 & C9 & $1.508(3)$ \\
C8 & C10 & $1.526(3)$ \\
C11 & C12 & $1.402(2)$ \\
C11 & C16 & $1.449(2)$ \\
C12 & C13 & $1.394(2)$ \\
C13 & C14 & $1.383(3)$ \\
C14 & C15 & $1.398(3)$ \\
C15 & C16 & $1.400(2)$ \\
& &
\end{tabular}

\begin{tabular}{lll}
\hline Atom & Atom & Length/A \\
\hline C17 & C18 & $1.536(3)$ \\
C18 & C19A & $1.530(5)$ \\
C18 & C19B & $1.531(4)$ \\
C18 & C20 & $1.513(3)$ \\
N1SA & C1SA & $1.521(3)$ \\
N1SA & C3SA & $1.524(3)$ \\
N1SA & C5SA & $1.526(3)$ \\
N1SA & C7SA & $1.514(3)$ \\
C1SA & C2SA & $1.528(4)$ \\
C3SA & C4SA & $1.508(3)$ \\
C5SA & C6SA & $1.513(3)$ \\
C7SA & C8SA & $1.526(3)$ \\
N1SB & C1SB & $1.521(3)$ \\
N1SB & C3SB & $1.524(3)$ \\
N1SB & C5SB & $1.527(3)$ \\
N1SB & C7SB & $1.512(3)$ \\
C1SB & C2SB & $1.528(5)$ \\
C3SB & C4SB & $1.508(4)$ \\
C5SB & C6SB & $1.514(4)$ \\
C7SB & C8SB & $1.526(4)$ \\
N2S & C9S & $1.518(2)$ \\
N2S & C11S & $1.526(2)$ \\
N2S & C13S & $1.525(2)$ \\
N2S & C15S & $1.514(2)$ \\
C9S & C10S & $1.514(3)$ \\
C11S & C12S & $1.511(3)$ \\
C13S & C14S & $1.512(3)$ \\
C15S & C16S & $1.524(3)$ \\
& &
\end{tabular}


Table S4. Crystallographic bond angles $\left(^{\circ}\right)$ for $\left(\mathrm{Et}_{4} \mathrm{~N}\right)_{2}[2]$.

\begin{tabular}{|c|c|c|c|c|c|c|c|}
\hline Atom & Atom & Atom & Angle/ ${ }^{\circ}$ & Atom & Atom & Atom & Angle $^{\circ}$ \\
\hline$\overline{N 1}$ & Co1 & N2 & $82.35(6)$ & $\overline{\mathrm{C} 15}$ & C16 & C11 & $118.8(1)$ \\
\hline N1 & Co1 & N3 & $83.13(6)$ & $\mathrm{O} 2$ & C17 & N3 & $127.4(2)$ \\
\hline N1 & Co1 & $\mathrm{C} 21$ & $134.86(6)$ & $\mathrm{O} 2$ & C17 & C18 & $118.1(2)$ \\
\hline N2 & Co1 & C21 & $109.30(6)$ & N3 & C17 & C18 & $114.4(2)$ \\
\hline N3 & Co1 & N2 & $139.18(6)$ & C19A & C18 & C17 & $109.0(9)$ \\
\hline N3 & Co1 & C21 & $107.97(6)$ & C19B & C18 & C17 & $108.1(2)$ \\
\hline C1 & $\mathrm{N} 1$ & Co1 & $114.8(1)$ & $\mathrm{C} 20$ & C18 & C17 & $112.3(2)$ \\
\hline C11 & N1 & Co1 & 114.7(1) & C20 & C18 & C19A & $129.5(9)$ \\
\hline C11 & N1 & C1 & 129.1(1) & C20 & C18 & C19B & $109.2(3)$ \\
\hline C6 & N2 & Co1 & $110.8(1)$ & N4 & $\mathrm{C} 21$ & Co1 & $179.5(2)$ \\
\hline C7 & N2 & Co1 & $127.0(1)$ & C1SA & N1SA & C3SA & $111.9(2)$ \\
\hline $\mathrm{C} 7$ & N2 & C6 & $120.8(1)$ & C1SA & N1SA & C5SA & $105.8(2)$ \\
\hline C16 & N3 & Co1 & $110.9(1)$ & C3SA & N1SA & C5SA & $111.3(2)$ \\
\hline C17 & N3 & Co1 & $125.4(1)$ & C7SA & N1SA & C1SA & $110.6(2)$ \\
\hline C17 & N3 & C16 & $123.0(1)$ & C7SA & N1SA & C3SA & 105.3(1) \\
\hline N1 & C1 & C2 & 129.1(1) & C7SA & N1SA & C5SA & $112.2(2)$ \\
\hline N1 & C1 & C6 & $113.7(1)$ & N1SA & C1SA & C2SA & $115.1(2)$ \\
\hline C2 & C1 & $\mathrm{C} 6$ & $117.2(1)$ & C4SA & C3SA & N1SA & $115.0(2)$ \\
\hline C3 & C2 & C1 & 121.7(2) & C6SA & C5SA & N1SA & $114.6(2)$ \\
\hline C4 & C3 & $\mathrm{C} 2$ & $120.5(2)$ & N1SA & C7SA & C8SA & $115.3(2)$ \\
\hline C3 & C4 & C5 & 119.4(2) & C1SB & N1SB & C3SB & $111.8(2)$ \\
\hline C6 & C5 & C4 & 121.2(2) & C1SB & N1SB & C5SB & $105.7(2)$ \\
\hline N2 & C6 & C1 & $115.4(1)$ & C3SB & N1SB & C5SB & $111.2(2)$ \\
\hline C5 & C6 & N2 & $124.7(1)$ & C7SB & N1SB & C1SB & $110.7(2)$ \\
\hline $\mathrm{C} 5$ & C6 & $\mathrm{C} 1$ & $120.0(1)$ & C7SB & N1SB & C3SB & $105.3(2)$ \\
\hline O1 & C7 & N2 & $126.4(2)$ & C7SB & N1SB & C5SB & 112.2(2) \\
\hline 01 & C7 & C8 & $118.9(1)$ & N1SB & C1SB & C2SB & $115.1(3)$ \\
\hline N2 & $\mathrm{C} 7$ & C8 & $114.7(1)$ & C4SB & C3SB & N1SB & $115.0(3)$ \\
\hline C9 & C8 & C7 & $112.1(2)$ & C6SB & C5SB & N1SB & $114.5(3)$ \\
\hline C9 & C8 & C10 & $112.5(2)$ & N1SB & C7SB & C8SB & $115.5(3)$ \\
\hline C10 & C8 & C7 & 107.4(2) & c9s & N2S & C11S & $108.4(1)$ \\
\hline N1 & C11 & C12 & $128.0(1)$ & C9S & N2S & C13S & $108.7(1)$ \\
\hline N1 & $\mathrm{C} 11$ & $\mathrm{C} 16$ & $114.3(1)$ & C13S & N2S & C11S & 111.4(1) \\
\hline C12 & C11 & C16 & 117.7(1) & C15S & N2S & c9s & $112.6(2)$ \\
\hline C13 & C12 & C11 & $121.9(2)$ & C15S & N2S & C11S & $108.6(1)$ \\
\hline C14 & C13 & C12 & $120.1(2)$ & C15S & N2S & C13S & 107.3(1) \\
\hline C13 & C14 & C15 & 119.8(2) & C10S & c9s & N2S & $115.6(2)$ \\
\hline C14 & C15 & C16 & $121.5(2)$ & C12S & C11S & N2S & $115.4(2)$ \\
\hline N3 & C16 & C11 & $114.9(1)$ & C14S & C13S & N2S & $115.0(2)$ \\
\hline C15 & C16 & N3 & 126.2(1) & N2S & C15S & C16S & $114.7(2)$ \\
\hline
\end{tabular}


Table S5. Selected experimental and calculated bond lengths $(\AA)$ and angles $\left(^{\circ}\right)$ for $[2]^{2-},[3]^{1-}$, and $[3 b]^{1-}$.

\begin{tabular}{|c|c|c|c|c|c|c|c|}
\hline & $\begin{array}{c}{[\mathbf{2}]^{2-}} \\
\text { (Experimental) }\end{array}$ & $\begin{array}{c}{[2]^{2-}(S=} \\
1 / 2)\end{array}$ & $\begin{array}{c}{[2]^{2-}(S=} \\
3 / 2)\end{array}$ & $\begin{array}{c}{[3]^{1-}(S=} \\
1 / 2)\end{array}$ & $\begin{array}{c}{[3]^{1-}(S=} \\
3 / 2)\end{array}$ & $\begin{array}{c}{[3 \mathbf{b}]^{1-}(S} \\
=1 / 2)\end{array}$ & $\begin{array}{c}{[3 \mathbf{b}]^{1-}(S} \\
=3 / 2)\end{array}$ \\
\hline Co - N1 $(\AA)$ & $1.950(1)$ & 1.905 & 1.965 & 1.849 & 1.972 & 1.91 & 1.949 \\
\hline $\begin{array}{c}\text { Co }- \text { N2 / } \\
\text { N3 (A) }\end{array}$ & $\begin{array}{c}2.010(1) / \\
1.997(2)\end{array}$ & $\begin{array}{l}1.959 / \\
1.965\end{array}$ & $\begin{array}{l}2.067 / \\
2.074\end{array}$ & $\begin{array}{l}1.900 / \\
1.922\end{array}$ & $\begin{array}{l}2.003 / \\
2.015\end{array}$ & $\begin{array}{c}2.014 / \\
2.021\end{array}$ & $\begin{array}{l}2.014 / \\
2.100\end{array}$ \\
\hline Co - C21 $(\AA)$ & $2.088(2)$ & 1.962 & 2.058 & --- & --- & --- & --- \\
\hline $\begin{array}{c}\mathrm{Co}-\mathrm{O} 1 / \mathrm{l} \\
\mathrm{O} 2(\AA)\end{array}$ & --- & --- & --- & 1.790 & 1.946 & $\begin{array}{l}1.810 / \\
1.905\end{array}$ & $\begin{array}{l}1.843 / \\
1.883\end{array}$ \\
\hline $\mathrm{C} 21-\mathrm{N} 4(\AA \mathrm{A})$ & $1.073(3)$ & 1.165 & 1.164 & --- & --- & --- & --- \\
\hline $01-02(\AA)$ & --- & --- & --- & 1.327 & 1.322 & 1.399 & 1.393 \\
\hline $\mathrm{N} 2-{ }_{\left({ }^{\circ}\right)} \mathrm{Co}-\mathrm{N} 3$ & $139.18(6)$ & 159.8 & 134.4 & 149.3 & 138.0 & 131.4 & 127.9 \\
\hline $\begin{array}{l}\mathrm{N} 1-\mathrm{Co}- \\
\mathrm{C} 21\left(^{\circ}\right)\end{array}$ & $134.86(6)$ & 136.1 & 135.0 & --- & --- & --- & --- \\
\hline $\begin{array}{c}\mathrm{N} 1-\mathrm{Co}-\mathrm{O} 1 \\
/ \mathrm{O} 2\left(^{\circ}\right)\end{array}$ & --- & --- & --- & 132.7 & 126.4 & $\begin{array}{c}117.9 / \\
162.0\end{array}$ & $\begin{array}{l}111.7 / \\
150.4\end{array}$ \\
\hline $\begin{array}{c}\mathrm{Co}-\mathrm{C} 21- \\
\mathrm{N} 4\left(^{\circ}\right)\end{array}$ & $179.5(2)$ & 177.9 & 179.2 & --- & --- & --- & --- \\
\hline Co $-\underset{\left({ }^{\circ}\right)}{\mathrm{O} 1}-\mathrm{O} 2$ & --- & --- & --- & 123.7 & 115.4 & $\begin{array}{l}64.3 / \\
71.5\end{array}$ & $\begin{array}{l}66.5 / \\
69.6\end{array}$ \\
\hline $\begin{array}{c}\mathrm{N} 1-\mathrm{Co}-\mathrm{N} 2 \\
/ \mathrm{N} 3\left(^{\circ}\right)\end{array}$ & $\begin{array}{c}82.35(6) / \\
83.13(6)\end{array}$ & $\begin{array}{l}84.1 / \\
84.2\end{array}$ & $\begin{array}{l}81.9 / \\
82.2\end{array}$ & $\begin{array}{l}84.7 / \\
83.5\end{array}$ & $\begin{array}{l}81.8 / \\
82.6\end{array}$ & $\begin{array}{l}81.6 / \\
82.8\end{array}$ & $\begin{array}{l}80.0 / \\
80.1\end{array}$ \\
\hline
\end{tabular}

\# Optimization was performed with BP86. All other optimizations performed with B3LYP. 
Table S6. Relative energies of ground states for $[3]^{1-}$ and $[3 b]^{1-\#}$.

\begin{tabular}{lcccc}
\hline & \multicolumn{2}{c}{ End-bound Superoxide [3] $]^{1-}$} & \multicolumn{2}{c}{ Side-bound Peroxide [3b] ${ }^{1-}$} \\
\cline { 2 - 4 } & Doublet & Quartet & Doublet & Quartet \\
\cline { 2 - 4 } Gibbs Energy $(\mathrm{kJ} / \mathrm{mol})$ & 0 & 7.05 & 17.61 & 26.11 \\
Favored Multiplicity? & Doublet $(\Delta \mathrm{G}=7.05 \mathrm{~kJ} / \mathrm{mol})$ & Doublet $(\Delta \mathrm{G}=8.50 \mathrm{~kJ} / \mathrm{mol})$ \\
Favored Coordination? & \multicolumn{2}{c}{ End-bound Superoxide $(\Delta \mathrm{G}=17.61 \mathrm{~kJ} / \mathrm{mol})$} \\
\hline
\end{tabular}

${ }^{*}=$ Relative to End-bound doublet

\# B3LYP was used for all of these calculations.

Note: Attempts were also made to optimize structures in which $[3]^{1-}$ and $[3 \mathbf{b}]^{1-}$ bind additional acetonitrile molecules to increase their coordination number. No such structures led to stable potential energy minima. 
Table S7. Spin multiplicities and energies of 15 electronic states of $[3]^{1-}$ calculated via SORCI using a CAS $(17,11)$ reference.

\begin{tabular}{ccc} 
State & $\begin{array}{c}\text { Spin } \\
\text { Multiplicity }\end{array}$ & $\begin{array}{c}\text { Energy Relative to Ground State } \\
\left(\mathbf{c m}^{\mathbf{- 1}}\right)\end{array}$ \\
\hline 0 & 2 & 0.0 \\
1 & 4 & 4663.1 \\
2 & 4 & 5168.5 \\
3 & 2 & 5241.8 \\
4 & 2 & 5327.9 \\
5 & 2 & 5734.7 \\
6 & 4 & 5917.2 \\
7 & 4 & 6730.9 \\
8 & 4 & 6972.3 \\
9 & 2 & 7110.3 \\
10 & 6 & 10150.5 \\
11 & 6 & 10302.9 \\
12 & 6 & 11896.1 \\
13 & 6 & 12784.6 \\
14 & 6 & 13176.0
\end{tabular}


$\mathrm{XYZ}$ Coordinates for quartet state $[\mathrm{Co}(\mathrm{L}) \mathrm{CN}]^{2-}[\mathbf{2}]^{2-}$

C -1.945046 $0.588023-2.011535$

$\begin{array}{llll}C & -2.921736 & 0.532154 & -3.026423\end{array}$

H $-3.250848-0.422644-3.401363$

C $-3.491247 \begin{array}{lll}1.680319 & -3.576690\end{array}$

H $-4.2462251 .578838-4.352625$

C $-3.0923082 .931187 \quad-3.135772$

H $-3.5417453 .832826-3.544024$

C $-2.1011533 .033661-2.154217$

H $-1.7583594 .001396-1.827261$

C $-1.4904861 .902726-1.597771$

C $0.2025023 .052727-0.287250$

C 1.4375702 .8326840 .608182

H 1.6626981 .7661680 .632583

C 2.6552513 .5498750 .019647

H $2.8623933 .206711-0.997128$

H 3.5450473 .3532670 .626893

H $2.481758 \quad 4.627435-0.018057$

C 1.1538413 .2914632 .041843

H 2.0441123 .1690602 .667996

H 0.3578772 .6992152 .490473

H $0.858188 \quad 4.3446292 .051089$

C $-1.208798-1.788047-1.779002$

C $-2.146454-2.547982-2.501684$

H $-3.092041-2.106720-2.775188$

C $-1.923254-3.884987-2.829755$

H $-2.679422-4.429892-3.389069$

C $-0.748557-4.506725-2.437580$

H $-0.557369-5.544760-2.696238$

C $0.197936-3.796084-1.694890$

H $1.112883-4.270679-1.379953$

C $0.006968-2.452193-1.353550$

C $2.167082-2.049319-0.324273$

C $3.029174-0.9603920 .347088$

H $2.368236-0.2310610 .817830$

$\begin{array}{llll}\text { C } 3.855895 & -0.249828 & -0.732481\end{array}$

H $4.4854890 .533302-0.297083$

H $3.2091100 .214426-1.478882$

H $4.504448-0.967192-1.243101$

C $3.928183-1.5512271 .430578$

H $3.333136-2.0075632 .224193$

H $4.552759-0.7712431 .879884$

H $4.574052-2.3220071 .005818$

Co -0.0984390 .0193080 .065851$

N $-1.325235-0.470021-1.388456$

N $-0.4144131 .918745-0.684872$

N $0.908360-1.661241-0.614651$

N $-0.223639-0.0375373 .284316$

C $-0.188543 \quad-0.0173252 .121478$

O $-0.094648 \quad 4.231523 \quad-0.562791$

$\begin{array}{llll}\text { O } & 2.720288 & -3.136771 & -0.580455\end{array}$ 
$\mathrm{XYZ}$ Coordinates for doublet state end-on superoxide $\left[\mathrm{Co}(\mathrm{L}) \mathrm{O}_{2}\right]^{1-}[\mathbf{3}]^{1-}$

\begin{tabular}{|c|c|c|c|}
\hline C & -1.773310211 & 0.627290480 & -2 \\
\hline C & -2.700847022 & 0.561922200 & -3.251877438 \\
\hline 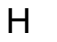 & -2.921040313 & 383427889 & \\
\hline C & -3.334281266 & 722148430 & -3 \\
\hline $\mathrm{H}$ & -4.053900776 & 1.656567884 & -4.5181873 \\
\hline J & -3.053056188 & 2.955320160 & -3.10299329 \\
\hline H & -3.565966340 & 3.857899772 & -3.439538302 \\
\hline J & -2.094248933 & 3.050587449 & -2.08877715 \\
\hline H & -1.849676533 & 4.014642112 & -1.65489697 \\
\hline C & 400 & & -1 \\
\hline C & 0.310724593 & 2.954518484 & $-0.27037962 C$ \\
\hline C & 1.297753603 & 2.765066047 & 0.882 \\
\hline $\mathrm{H}$ & 1.491558714 & 1.691219325 & 1.0280663 \\
\hline C & 2.625602054 & 3.473271648 & 0.58392874 \\
\hline $\mathrm{H}$ & 3.103123593 & 3.069475814 & -0.320635160 \\
\hline $\mathrm{H}$ & 3.3208 & 002966 & 595 \\
\hline $\mathrm{H}$ & 2.4633 & 17204 & 0.4 \\
\hline C & 0.6 & & \\
\hline H & 1.343 & 3.17 & 3.0 \\
\hline $\mathrm{H}$ & $-0.2774 \varepsilon$ & 2.76 & 2.4 \\
\hline $\mathrm{H}$ & 0.423873338 & 4.373328927 & 2.071512808 \\
\hline C & -1.147814666 & -1.786078489 & -1.826064507 \\
\hline C & -2.173195011 & -2.518635667 & -2.45436677 \\
\hline $\mathrm{H}$ & -3.05 & -2.0 & -2 \\
\hline C & $-2.0 \varsigma$ & -3.9 & -2 \\
\hline $\mathrm{H}$ & -2.9 & & \\
\hline C & -0.99 & -4.5 & 3738 \\
\hline $\mathrm{H}$ & -0.94 & -5.6 & $-2 .($ \\
\hline C & 0.021688691 & -3.882381865 & -1.333089128 \\
\hline $\mathrm{H}$ & 0.864436031 & -4.405952270 & -0.891511001 \\
\hline C & -0.034488490 & -2.482510330 & -1.253720972 \\
\hline C & 2.211 & -1.9 & -0.4 \\
\hline C & 3.1 & & \\
\hline 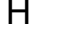 & 2.48 & -0.0 & 05 \\
\hline C & 3.95 & -0.25 & 0115 \\
\hline $\mathrm{H}$ & 4.628214928 & 0.504630077 & -0.757828232 \\
\hline $\mathrm{H}$ & 3.319867444 & 0.119037746 & -1.903255594 \\
\hline $\mathrm{H}$ & 4.575582764 & -1.093778868 & -1.544305322 \\
\hline C & 4.013575039 & -1.364544446 & 1.193666082 \\
\hline $\mathrm{H}$ & 3.410886601 & -1.71740 & 5379 \\
\hline $\mathrm{H}$ & 4.67 & & \\
\hline $\mathrm{H}$ & & -2.1 & 90 \\
\hline Co & & 84 & -0.1 \\
\hline $\mathrm{N}$ & -1.089528016 & -0.416767812 & -1.592163449 \\
\hline $\mathrm{N}$ & -0.387360325 & 1.830785357 & -0.681005208 \\
\hline $\mathrm{N}$ & 0.885994426 & -1.627238461 & -0.618937358 \\
\hline 0 & 0.916825313 & -0.295674291 & 2.393781207 \\
\hline O & -0.114616442 & -0.102404461 & 1.581293842 \\
\hline $\mathrm{O}$ & 0.1 & 4.084671 & -0.764348381 \\
\hline h & 2.700976972 & -3.053118660 & -0.79515162 \\
\hline
\end{tabular}


$\mathrm{XYZ}$ Coordinates for doublet state side-on peroxide $\left[\mathrm{Co}(\mathrm{L}) \mathrm{O}_{2}\right]^{1-}[3 \mathbf{b}]^{1-}$

Co $-0.171269-0.0811490 .074362$

O $-1.367879-0.6199821 .321098$

O $-0.232809-0.1328791 .977451$

N $-0.667376-0.234817-1.764154$

N $-0.3089741 .881147-0.358835$

N $1.200164-1.472074-0.443229$

C $-1.428843 \quad 0.840780-2.187319$

C $-2.3527400 .846974-3.242977$

H $-2.535787-0.059715-3.801678$

C $-3.1057151 .979495-3.509255$

H $-3.8380301 .965999-4.308233$

C $-2.9320183 .123752-2.729051$

H $-3.5207284 .010720-2.937729$

C $-2.0296823 .144645-1.674779$

H -1.901133 $4.032861-1.079221$

C -1.250890 $2.011961-1.375236$

C $0.2649392 .960747 \quad 0.262283$

C 1.3729322 .6088731 .263057

H 1.1126291 .6591401 .727605

C 2.6961562 .4485040 .494587

H $2.624611 \quad 1.667483-0.263198$

H 3.5086702 .1818041 .175469

H $2.9657593 .381617-0.007490$

C 1.4999613 .6624432 .359778

H 2.2894763 .3775653 .061367

H 0.5704473 .7635332 .923169

H 1.7446854 .6382441 .936938

C $-0.005472-1.172233-2.483240$

C $-0.114919-1.390855-3.876770$

H $-0.750477-0.749961-4.467720$

C $0.584943-2.408024-4.484443$

H $0.476294-2.575851-5.550225$

C $1.439581-3.222561-3.723503$

H $1.985179-4.025822-4.206344$

C $1.621201-3.002156-2.372850$

H $2.294835-3.622066-1.806331$

C $0.951895-1.943857-1.714688$

C $2.044337-2.1419490 .435818$

C $2.666668-1.284083 \quad 1.542163$

H $2.239606-0.2873221 .486200$

C $4.177969-1.190588 \quad 1.289797$

H $4.645232-0.5465282 .038808$

H $4.400442-0.7719150 .305399$

H $4.638700-2.1780861 .353364$

C $2.385834-1.8642582 .929671$

H $1.318681-1.8337393 .144776$

H $2.902173-1.2766053 .693664$

H $2.741300 \quad-2.8952392 .991210$

$\begin{array}{llllll}\text { O } & 0.020108 & 4.141627 & 0.009177\end{array}$

O $2.355922-3.3254520 .347885$ 


\section{References.}

1. (a) Evans, D. F. J. Chem. Soc. 1959, 2003-2005; (b) Bain, G. A.; Berry, J. F. J. Chem. Ed. 2008, 85 (4), 532.

2. $\quad$ Stoll, S.; Schweiger, A. J. Magn. Reson. 2006, 178 (1), 42-55.

3. Bruker-AXS. APEX2; v. 2014.11-0.

4. Bruker-AXS. SAINT; v. 7.68A; 2009.

5. Krause, L.; Herbst-Irmer, R.; Sheldrick, G. M.; Stalke, D. J. Appl. Cryst. 2015, 48, 3-10.

6. Sheldrick, G. M. XS; Georg-August-Universitat: Gottingen, Germany, 2008.

7. (a) Sheldrick, G. M. Acta Cryst. A 2008, 64, 112-122; (b) Dolomanov, O. V., Bourhis, L. J., Gildea, R. J., Howard, J. A. K., Puschmann, H. J. Appl. Cryst. 2009, 42, 339-341.

8. Sheldrick, G. M. Acta Cryst. C 2015, 71, 3-8.

9. Delgado-Jaime, M. U.; Mewis, C. P.; Kennepohl, P. J. Synchrotron Radiat. 2010, 17, 132-137.

10. (a) Neese, F. WIREs Comput. Mol. Sci. 2012, 2 (1), 73-78; (b) Neese, F. ORCA, An Ab Initio, Density Functional and Semi-empirical Program Package; Max-Planck-Institute for Bioinorganic Chemistry: Ruhr, Germany, 2012.

11. (a) Perdew, J. P. Phys. Rev. B 1986, 33 (12), 8822-8824; (b) Becke, A. D. Phys. Rev. A 1988, 38 (6), 3098-3100.

12. (a) van Lenthe, E.; Snijders, J. G.; Baerends, E. J. J. Chem. Phys. 1993, 99, 4597; (b) van Wullen, C. J. Chem. Phys. 1998, 109, 392-399.

13. (a) Schafer, A.; Horn, H.; Ahlrichs, R. J. Chem. Phys. 1992, 97 (4), 2571-2577; (b) Pantazis, D. A.; Chen, X.-Y.; Landis, C. R.; Neese, F. J. Chem. Theory Comput. 2008, 4 (6), 908-919.

14. (a) Klamt, A.; Schuurmann, G. J. Chem. Soc., Perkin Trans. 21993, (5), 799-805; (b) Sinnecker, S.; Rajendran, A.; Klamt, A.; Diedenhofen, M.; Neese, F. J. Phys. Chem. A 2006, 110, 2235-2245.

15. DeBeer George, S.; Petrenko, T.; Neese, F. J. Phys.Chem. A 2008, 112 (50), 1293612943.

16. (a) Vosko, S. H.; Wilk, L.; Nusair, M. Can. J. Phys. 1980, 58 (8), 1200-1211; (b) Lee, C.; Yang, W.; Parr, R. G. Phys. Rev. B 1988, 37 (2), 785-789; (c) Becke, A. D. J. Chem. Phys.

1993, 98 (2), 1372-1377; (d) Stephens, P. J.; Devlin, F. J.; Chabalowski, C. F.; Frisch, M. J. J. Phys. Chem. 1994, 98 (45), 11623-11627.

17. Weigend, F.; Ahlrichs, R. Phys. Chem. Chem. Phys. 2005, 7 (18), 3297-3305.

18. (a) Dunning, T. H. J. Chem. Phys. 1989, 90 (2), 1007-1023; (b) Kendall, R. A.; Dunning, T. H.; Harrison, R. J. J. Chem. Phys. 1992, 96 (9), 6796-6806; (c) Woon, D. E.; Dunning, T. H. J. Chem. Phys. 1993, 98 (2), 1358-1371; (d) Woon, D. E.; Dunning, T. H. J. Chem. Phys. 1994, 100 (4), 2975-2988.

19. Neese, F.; Wennmohs, F.; Hansen, A.; Becker, U. Chem. Phys. 2009, 356 (1-3), 98-109.

20. Weigend, F. Phys. Chem. Chem. Phys. 2006, 8 (9), 1057-1065.

21. Neese, F. J. Phys. Chem. Solids 2004, 65 (4), 781-785.

22. Pettersen, E. F.; Goddard, T. D.; Huang, C. C.; Couch, G. S.; Greenblatt, D. M.; Meng,

E. C.; Ferrin, T. E. J. Comput. Chem. 2004, 25, 1605-1612.

23. Avogadro: An open-source molecular building and visualization tool; 1.0.3.

http://avogadro.openmolecules.net/.

24. Neese, F. J. Chem. Phys. 2003, 119, 9428-9443.

25. Neese, F. J. Am. Chem. Soc. 2006, 128, 10213-10222.

26. Sorrell, T. N.; Malachowski, M. R. Inorg. Chem. 1983, 22 (13), 1883-1887. 